\title{
Stock Redemptions and Partial Liquidations Under the Internal Revenue Code of 1954
}

\author{
BORIS I. BITTKER*
}

\section{INTRODUCTION}

When a shareholder transfers to a corporation its own stock in exchange for money or other property, the transaction may resemble either an ordinary sale of stock to an outsider in an arm's length bargain or the receipt by the shareholder of a dividend from the corporation. The "sale" analogy is appropriate, for example, when the owner of preferred stock instructs his broker to sell his stock and the broker by chance effects a sale to the corporation, which happens to be buying up its preferred stock at the time. The preferred shareholder ought to be able to treat the transaction like any other sale, reporting the difference between his adjusted basis and the sales price as capital gain or loss. On the other hand, when the owner of a one-man corporation having only common stock outstanding forgoes dividends for a period of years and then sells some of his shares to the corporation for cash, the transaction is more like a "dividend" than a "sale." Although the shareholder has surrendered some of his stock, his interest in the corporation's assets and his control of the corporation's fate are undisturbed. If the transaction were not taxed as a "dividend," moreover, the shareholder could enter upon a long-range program of intermittent transfers of stock to his corporation, employing tax-free stock dividends if necessary to replace his shares and to restore the corporation's stated capital for the benefit of nervous creditors. For shareholders who could adopt such a plan of intermittent "sales" of stock, the tax on dividend income would become a dead letter.

It should not be surprising, then, that a sale of stock by a shareholder to his corporation is sometimes taxed as a dividend instead of a sale. The knotty problem that has faced Congress, the Treasury and the courts over the years-a problem for which there can never be a universally acceptable solution-is the determination of which transfers of stock are to be classified as "dividends" and

* A.B., Comell University, 1938; LL.B., Yale Law School, 1941; Professor of Law, Yale Law School. 
which as "sales." For a period of more than thirty years, ending in 1954, the general rule was that such transactions were sales ${ }^{2}$ unless the transaction was "essentially equivalent to the distribution of a taxable dividend," in which event the entire distribution was taxed as a dividend to the extent of current and post-rgr3 earnings and profits. ${ }^{3}$ Although the r954 Code seeks to provide a more reliable formula, it preserves this ancient and troublesome phrase. ${ }^{4}$ Thus there is no escape from a few words of history before we turn to the statutory language of the I954 Code.

The "essentially equivalent" phrase first appeared in the Revenue Act of rg2r. ${ }^{6}$ On providing that stock dividends should not be taxed, ${ }^{7}$ Congress recognized the possibility, already described, that stock dividends might be issued and then promptly redeemed as a

1. Throughout this Article the statement that a distribution in redemption of stock is to be treated as a "dividend" is predicated on an assumption that the corporation has earnings and profits to cover the amount of the distribution. The statement that a redemption is to be treated as a "sale" or an "exchange" means that the distribution in redemption of stock is to be treated as payment in exchange for the stock. It is assumed throughout that the redeemed stock is a capital asset in the hands of the shareholder; this will ordinarily be true of any taxpayer except a dealer in securities.

2. The statute was not uniform throughout this period. Gain on partial liquidations was taxable as ordinary income from 1934 to 1936, Revenue Act of 1934, $\$ 115,48$ STAT. 711 , and as short-term capital gain (regardless of the holding period) from 1936 to 1942. Revenue Act of 1936, $\$ 115,49$ STAT. 1687. For a history of the statutory provisions, see Darrell, Corporate Liquidations and the Federal Income Tax, 89 U. PA. L. REv. 907 (1941).

3. Int. Rev. Code of $1939, \$ 115(\mathrm{~g}), 53$ STAT. 48.

4. INT. REv. CODE OF 1954, \$\$302(b), 346(a)(2).

5. For pre-1954 law, see Bittker \& Redlich, Corporate Liquidations and the Income Tax, 5 TAx L. REv. 437, 455 (1950); Cohen, A Technical Revision of the Federal Income Tax Treatment of Corporate Distributions to Shareholders, 52 Colum. L. REv. 1, 24-38 (1952) (discussing the A.L.I. proposals); Darrell, stipra note 2; Murphy, Partial Liquidations and the New Look, 5 TAx L. Rev. 73 (1949); Nolan, The Uncertain Tax Treatment of Stock Redemptions: A Legislative Proposal, 65 Harv. L. Rev. 255 (1951); Pedrick, Some Latter Day Developments in the Taxation of Liquidating Distributions, $50 \mathrm{Mrcr}$. L. REv. 529 (1952).

For the 1954 changes, see the following, all written before the Regulations were promulgated: Bittker, Stock Dividends, Distributions in Kind, Redemptions, and Liquidations Under the 1954 Code, 1955 So. Calif. Tax Inst. 349, 370; Chommie, Section 346 (a) (2): The Contraction Theory, 11 TAx L. REv. 407 (1956); Cohen, Corporate Liquidations Under the Internal Reventie Code of 1954, 55 Colum. L. Rev. 37, 51 (1955); Cohen, Redemptions of Stock Under the Internal Reventse Code of 1954, 103 U. PA. L. REv. 739 (1955); Laikin, Stock Redemptions: Sections 302 and 318, N.Y.U. 14TH INST. ON FED. TAx. 671 (1956); Murphy, Dividend Equivalency-The End of the Beginning?, 10 TAx L. REv. 213 (1955); Oberndorfer, Partial Liquidations, N.Y.U. 13 TH INST. ON FED. TAX. 637 (1955); Owen, Stock Redemptions and Partial Liquidations Under the 1954 Code, 32 TAxes 979 (1954); Silverstein, Stockholder Gains and Losses on Partial Liquidations, N.Y.U. 14t7 INST. ON FED. TAX. 707 (1956); Windhorst, Stock Redemptions and Constructive Ownership Problems, 33 TAxes 917 (1955); Winton \& Hoffman, $A$ Case Study of Stock Redemptions Under Sections 302 and 318 of the New Code, 10 TAX L. REv. 363 (1955); Wolfman, Some of the Attribution-of-Ownership Problems Involved in the Redemption of Stock Under the 1954 Code, 33 Taxes 382 (1955); Note, Redemptions and Parial Liquidation Under the 1954 Internal Revenue Code: The Dividend Equivalence Test, 103 U. PA. L. Rev. 936 (1955).

6. Revenue Act of 1921, §201(d), 42 Stat. 228, 229.

7. Id. at 228 . 
substitute for ordinary cash dividends. Congress went on, therefore, to provide that the redemption of stock "after the distribution of any such [stock] dividend" could be taxed as a dividend if the transaction was "essentially equivalent to the distribution of a taxable dividend." This provision failed to reach a redemption that was followed, rather than preceded, by a stock dividend, but that omission was corrected in I924..$^{\circ}$ Two years later, the provision, which became section $\operatorname{II}_{5}(\mathrm{~g})$ of the $1939 \mathrm{Code}^{10}$ was amended to apply whenever a corporation cancelled or redeemed its stock "at such time and in such manner as to make the distribution and cancellation or redemption in whole or in part essentially equivalent to the distribution of a taxable dividend," whether or not such stock was issued as a stock dividend. ${ }^{11}$

Despite this change, the courts at one time were reluctant to apply section $\operatorname{II}_{5}(\mathrm{~g})$ unless the redeemed shares had been issued as tax-free stock dividends or in anticipation of a later redemption. ${ }^{12}$ Later, however, the courts viewed section $\operatorname{Ir}_{5}$ (g) more sympathetically, in that they came increasingly to start with the assumption that any pro rata redemption was equivalent to a taxable dividend, casting on the taxpayer the burden of establishing that it ought to be treated as a sale instead. ${ }^{13}$ As section $\operatorname{Ir}_{5}(\mathrm{~g})$ came to

\section{Ibid.}

9. Revenue Act of $1924, \S 201(\mathrm{f}), 43$ Stat. 255. The statute did not provide the Commissioner with a device to predict whether a redemption would be followed by a stock dividend.

10. Int. Rev. Code of $1939, \S 115(\mathrm{~g}), 53$ STAT. 48.

11. Revenue Act of $1926, \$ 201(\mathrm{~g}), 44$ STAT. 11.

12. Murphy, Partial Liquidations and the New Look, 5 TAx L. Rev. 73 (1949).

13. See $i d$. at 84-85. The "old" Regulations provided: "A cancellation or redemption by a corporation of a portion of its stock pro rata among all the shareholders will gencrally be considered as effecting a distribution essentially equivalent to a dividend .... On the other hand, a cancellation or redemption by a corporation of all of the stock of a particular shareholder, so that the shareholder ceases to be interested in the affairs of the corporation, does not effect a distribution of a taxable dividend." U.S. Treas. Reg. 118, $\$ 39.115(\mathrm{~g})-1$ (a) (2) (1954). For an interpretation of the phrase "ceases to be interested in the affairs of the corporation," see Rev. Rul. 54-408, 1954-2 Cum. BuLL. 165.

Although these regulations explicitly provided only that a redemption of "all" of the stock of a particular shareholder escaped $\S 115(\mathrm{~g})$, the position was taken that a redemption of part of the stock of a particular shareholder was equally efficacious. "It changes, pro tanto, his interest in the corporation in the same way that redemption of all his stock would do." Ferris v. United States, 135 F. Supp. 286, 288 (Ct. Cl. 1955). As to redemptions that are superficially non-pro rata, but are pro rata in reality either because the loss of the redeemed shares does not seriously affect the shareholder's relative position or because he is closely related to the remaining shareholders, see Pullman, Inc., 8 T.C. 292, 297 (1947); J. C. Natwick, 36 B.T.A. 866, 876 (1937). Sce also note 69 infra.

While the older theory that $\$ 115(\mathrm{~g})$ was to be applied only to shares issued as stock dividends was almost totally abandoned, a trace of it may be detected in certain cases holding that a redemption of stock (especially preferred stock) issued for cash with an understanding that it would be redeemed when the corporation was financially able to do so is not essentially equivalent to a dividend. See, e.g., Giles E. Bullock, 26 T.C. No. 35 (May 18, 1956); Marjory K. Hatch, $13 \mathrm{CCH}$ TAx CT. MEM. 371 (1954); G. E. Nicholson, 17 
be the norm by which all pro rata redemptions were tested, rather than the exception, taxpayers found their safest escape in a judicial doctrine that a redemption resulting from a "corporate contraction" (or a "legitimate shrinkage") in the corporation's business activities was not essentially equivalent to a dividend. ${ }^{14}$ The courts also agreed that a redemption for "legitimate business purposes" was not taxable under section $\operatorname{II}(\mathrm{g})$, without, however, agreeing on the meaning of that phrase. ${ }^{15}$ Even less helpful was the solemn announcement that the true test was whether the "net effect" of the redemption was the distribution of a dividend. In its infancy, this test was an attempt to escape an inquiry into the motives and plans of the shareholder and his corporation. ${ }^{16}$ But since virtually all pro rata redemptions have the net effect of a dividend, the courts finally succeeded in converting this test into a restatement of the "essentially equivalent" language of the statute, or, sometimes, into a pseudonym for the "business purpose" doctrine which it was created to avoid. ${ }^{17}$ In applying section $\operatorname{IIS}_{5}(\mathrm{~g})$ there proved to be no escape from an inquiry into all the facts and circumstances of each case, and predictions were hazardous:

Above all, courts continued to look for a valid business purpose of the corporation, such as ( $\mathrm{I}$ ) enabling the business to operate more efficiently as a sole proprietorship or as a partnership, (2) the conduct of part of its business under separate corporate form, (3) enhancement of its credit rating by calling in stock to cancel stockholder indebtedness, (4) resale

T.C. 1399 (1952); Rev. Rul. 55-462, 1955-2 CuM. BuLl. 221 The same result was reached where the redeemed shares had been issued to pay a corporate debt. Keefe v. Cote, 213 F.2d 651 (1st Cir. 1954); Golwynne's Estate, 26 T.C. No. 151 (Sept. 28, 1956).

14. Bittker \& Redlich, Corporate Liquidations and the Income Tax, 5 TAx L. REv. 437, 471-72 (1950); Chommie, Section 346(a)(2): The Contraction Theory, 11 Tax L. REv. 407, 417-22 (1956).

15. See Bittker \& Redlich, Corporate Liquidations and the Income Tax, 5 TAX L. REv. $437,470-71$ (1950).

16. Flanagan v. Helvering, 116 F.2d 937, 939-40 (D.C. Cir. 1940) ("but the net effect of the distribution, rather than the motives and plans of the taxpayer or his corporation, is the fundamental question in administering $\$ 115[\mathrm{~g}] "$ ").

17. "But the courts generally have not applied the 'net effect' test with strict logic but have broadened its scope to include inquiry into the possible existence of some legitimate business purpose,' for the redemption, that is to say, a legitimate corporate purpose as distinguished from a purpose to benefit the stockholder by a distribution of accumulated earnings and profits exempt from the imposition of income tax ...., thus adding a question of motive to the question of ultimate result." Keefe v. Cote, 213 ' F.2d 651, 657 (1st Cir. 1954). The wheel came full circle in Golwynne's Estate, 26 T.C. No. 151 (Sept. 28, 1956). "Since Flanagan v. Helvering . . . the courts have relied repeatedly on the so-called net effect test to determine the factual question here presented. That is to say, if the 'net effect' of a stock redemption and distribution is essentially equivalent to a dividend distribution, then it is so taxed; if not, if a legitimate business purpose prompted the redemption and distribution, then it is not taxable as a dividend." Ibid. In Commissioner v. Sullivan, 210 F.2d 607 (5th Cir. 1954), on the other hand, Judge Holmes wrote: "The net-effect test is not a test but an attractive abbreviation of the statute . . . ." Id. at 609 . 
of stock to junior executives, (5) provision of a profitable investment for an employees' association, (6) adjustment for a legitimate shrinkage of the business following a fire causing a permanent reduction in productive capacity, (7) elimination of unprofitable departments, or (8) contemplation of ultimate liquidation.

Other factors than business purpose entered into the witch's brew. While the pro-rata feature is seldom disregarded and often held controlling, its effect is not always predictable and courts at times find no dividend, though the redemption is pro-rata and upon occasion even find that a nonpro-rata distribution requires dividend treatment. Other factors of varying degrees of significance have been held to be a poor dividend record, combined with large available earnings or profits; the fact that the initiative for the distribution was taken by the shareholder, rather than by the corporation; and the fact that the consideration paid for the redeemed stock bears no relation to its value, book or otherwise. ${ }^{18}$

Before I954 the statute did not distinguish between "redemptions" and "partial liquidations"; in fact, the term "partial liquidation" was defined as "a distribution by a corporation in complete cancellation or redemption of a part of its stock." ${ }^{19}$ This, the draftsmen of the 1954 Code thought, led to confusion:

Existing law is complicated by the fact that stock redemptions are included within the terms of the partial liquidation provisions. Thus, a redemption of all of the stock of $\mathrm{I}$ of 2 sole shareholders of a corporation may result in capital-gain treatment to the redeemed shareholder. The result occurs, however, not by reason of the use of any particular assets of the corporation to effect the redemption but because the distribution when viewed at the shareholder level is so disproportionate with respect to the outstanding shareholder interests as not to be substantially equivalent to a dividend.

Your committee, as did the House bill, separates into their significant elements the kind of transactions now incoherently aggregated in the definition of a partial liquidation. Those distributions which may have capital-gain characteristics because they are not made pro rata among the various shareholders would be subjected, at the shareholder level, to the separate tests described in part I of this subchapter. On the other hand, those distributions characterized by what happens solely at the corporate level by reason of the assets distributed would be included as within the concept of a partial liquidation. ${ }^{20}$

18. Treusch, Corporate Distributions and Adjustments: Recent Case Reminders of Some Old Problems Under the New Code, 32 TAXEs 1023, 1037 (1954). For cases in which the applicability of $\S 115(\mathrm{~g})$ was submitted to a jury, see Jones v. Griffin, 216 F.2d 885 (10th Cir. 1954); Keefe v. Cote, 213 F.2d 651 (1st Cir. 1954).

19. Int. Rev. Code of 1939, \$115(i), 53 STAт. 48. The definition (which strictly speaking was a definition of the term "amounts distributed in partial liquidation") also embraced "one of a series of distributions in complete cancellation or redemption of all or a portion of its stock."

20. S. Rep. No. 1622, 83d Cong., 2d Sess. 49 (1954) [hereinafter cited as Senate REPORT]. 
The language of the r954 Code, however, fails hopelessly in its aim of separating partial liquidations from redemptions. According to section 346 (a), a partial liquidation (which is to be treated like a sale of the surrendered stock) includes a distribution "in redemption of a part of the stock of the corporation" that is "not essentially equivalent to a dividend." Nothing is said in section 346(a) about distributions characterized by what happens solely at the corporate level or about corporate contractions. Yet section 346 is the section that is supposed to provide the exclusive rule for partial liquidations, segregating them from other redemptions. Not only is section 346 (a) innocent of any reference to corporate contractions, but its language is virtually identical with parts of section 302, the section designed by the draftsmen of the 1954 Code to deal exclusively with those redemptions that are not partial liquidations. For section 302 provides, among other things, that a redemption shall be treated as a sale of the stock if it "is not essentially equivalent to a dividend." If the draftsmen's goal of separating into their significant elements the kind of transactions incoherently aggregated by the r939 Code in the definition of a partial liquidation is achieved, it will be by the painful process of administrative and judicial construction of muddy language.

Moreover, whatever simplicity is gained by the new statutory framework is easily outweighed by the complications introduced by the distinction between "distributions characterized by what happens solely at the corporate level by reason of the assets distributed" (i.e., partial liquidations) and "distributions which may have capital-gain characteristics because they are not made pro rata among the various shareholders" (i.e., certain other redemptions). ${ }^{21}$ To determine whether a redemption of stock is to be treated as a sale or as a dividend under the 1954 Code, it often will be necessary to examine section 302 , relating to ordinary redemptions, as well as sections $33 \mathrm{r}(\mathrm{a})(2)$ and 346 , relating to partial liquidations. ${ }^{22}$ The following discussion will deal first with the

21. Ibid.

22. In the opinion of the author, the transfer of stock by a shareholder to his corporation for consideration can qualify as a sale or exchange of a capital asset only if it meets the standards of $\S 302(\mathrm{a}), \S 331$ (a)(2) or $\$ 303$. I do not believe, in other words, that such a transaction between the shareholder and his corporation can qualify for capital gain or loss treatment on the independent ground that it is a sale of stock rather than a redemption and that only the latter category must run the gauntlet of $\S 302(a), \S 331(\mathrm{a})(2)$ and $\$ 346$, as is suggested by one writer. Chommie, Section $346(a)(2)$ : The Contraction Theory, 11 TAX L. REv. 407, 415-16 (1956). At one time, to be sure, the courts distinguished between the proceeds of a partial liquidation and the proceeds of a sale of stock to 


\section{partial liquidation test ${ }^{23}$ and then will treat stock redemptions. Finally, attention will be given to collateral problems.}

the issuing corporation. The distinction was created during the period when gains on partial liquidations were treated as ordinary income (1934-36) or as short-term capital gain (193642). See note 2 supra. If the shareholder could persuade the court that he had sold his shares to the corporation, rather than surrendered them in a partial liquidation, his gain would be long-term capital gain (assuming the shares had been held for the appropriate period of time), rather than ordinary income or short-term capital gain. Since the term "partial liquidation" was defined in $\$ 115(\mathrm{~g})$ of the 1939 Code to mean "a distribution by a corporation in ... cancellation or redemption" of stock, some courts held that a transaction constituted a sale rather than a partial liquidation if the shares were held in the treasury and not cancelled or retired. See cases cited note 53 infra.

Another criterion for distinguishing between sale and partial liquidation was whether the corporation was winding up or permanently reducing its assets; if not, and especially if the shares were to be reissued, there was a tendency to hold that the transaction was a sale of shares to the corporation rather than a partial liquidation. Bittker, Stock Dividends, Distributions in Kind, Redemptions, and Liquidations Under the 1954 Code, 1955 So. Calif. TAx Inst. 349, 458-65; Kaufman, How to Treat Stock Redemptions, N.Y.U. 9TH INST. ON FED. TAX. 1007, 1009-12 (1951). The distinction declined in importance after 1942, when partial liquidations became entitled to long-term capital gain treatment once more. Int Rev. Code of 1939, $\$ 115$, as amended, 56 STAT. 841 (1942). However, it lingered on, since a transaction that could be characterized as a sale did not have to withstand the test of $\$ 115(\mathrm{~g})$. Another application of the distinction is to be found in Bernard Rubin, 5 CCH Tax Ct. Mem. 216 (1946), where a loss on a transfer of stock by a shareholder to a controlled corporation was disallowed because the transaction was a sale rather than a liquidation under what is now $\$ 267$.

Under subchapter C of the 1954 Code, however, it is doubtful that the category of sale still exists as an independent category of transactions between the shareholder and his corporation. Section 317 (b) provides that "stock shall be treated as redeemed by a corporation if the corporation acquires its stock from a shareholder in exchange for property, whether or not the stock so acquired is cancelled, retired, or held as trcasury stock." This definition obliterates the distinction between stock that is cancelled or retired and stock that is held in the treasury at least for purposes of part I of subchapter C. It also seems to embrace all transactions by which the corporation acquires stock from its shareholders for consideration, leaving no room for a sale of stock to the corporation. This conclusion is reinforced by the fact that $\$ 302(b)(1)$ was enacted partly to deal with isolated transactions that, before 1954 , would have been regarded as sales. See pp. 41-45 infra.

Moreover, it was thought by some observers that the 1939 Code lent color to the distinction between sale and partial liquidation by using the term "distributions" in reference to the latter. It was argued that a distribution contemplates "a ratable, permanent transfer" of assets to the shareholders, to be distinguished from a purchase of stock by the corporation for resale. Kaufman, supra at 1009. The 1954 Code retains the phrase "distributed" in $\$ 331(\mathrm{a})(2)$ and in $\S 346$, but $\$ 317(\mathrm{~b})$, as indicated above, provides that if a corporation "acquires its stock from a shareholder in exchange for property" it "shall be treated as redeemed," and $\S 302(\mathrm{a})$ and $\$ 302$ (d) provide that a redemption "shall be treated as a distribution." The colorless language of $\$ 317$ (b) thus scems clearly to embrace any acquisition of stock for a consideration, whether the transaction would have been a "distribution" under the pre-1954 criteria or not.

A special, but minor, problem is presented by a transaction in which a shareholder buys property from his corporation and pays for it in stock. From the corporation's point of view, this is a sale of the property on which gain or loss is recognized rather than a distribution under $\$ 311(\mathrm{a})$. See note 164 infra. But from the point of view of the shareholder, the stock has probably been redeemed within the meaning of $\$ 317$ (b).

23. The Regulations take the position that if a distribution qualifies under $\$ 346$ as a partial liquidation, $\$ 302$ is not applicable to it. T.D. 6152,26 C.F.R. $\$ \$ 1.346-2$, $1.302-1$ (a) (1955). Often it will be immaterial to the shareholder which section is employed, assuming his distribution qualifies under both $\S 346$ and $\S 302$ (a), but $\S 346$ will be preferable if section 306 stock is redeemed under $\$ 306(b)(2)$ or if LIFO inventory or property subject to a liability is distributed. See Chommie, Section 346(a)(2): The Contraction Theory, 11 TAx L. REv. 407, 413-14 (1956). See also pp. 58-59 infra. Moreover, $\$ 267$, which disallows losses on certain "sales or exchanges of property," does not apply to "distributions in corporate liquidations." This exemption formerly em- 


\section{Partial Liquidattons}

Section 33I(a) (2) provides that amounts distributed in partial liquidation of a corporation shall be treated as payment in exchange for the stock. If the stock is a capital asset in the hands of the shareholder, which is normally the case, his gain or loss (the difference between the value of the distribution and the adjusted basis of the redeemed stock) ${ }^{24}$ will be capital gain or loss, long- or short-term depending upon his holding period for the stock. While section $33 \mathrm{I}(\mathrm{a})(2)$ is the operative provision, requiring the distribution in partial liquidation to be treated like the proceeds of a sale of the stock, it is dependent upon section 346, which defines the term "partial liquidation." ${ }^{25}$ Section 346 provides that a distribution "shall be treated as in partial liquidation" of a corporation if it falls into one of three categories: ${ }^{26}$

I) A distribution that is one of a series of distributions in complete liquidation of the corporation. ${ }^{27}$ This category of partial liquidations could have been classed with complete liquidations; it does not invoke the "corporate contraction" concept that is ordinarily associated with the term "partial liquidation."

2) A distribution in redemption of part of the stock of a corporation that is "not essentially equivalent to a dividend."2s This category of partial liquidations is "characterized by what happens solely at the corporate level by reason of the assets distributed,"29 i.e., it is a statutory adoption of the "corporate contraction" concept created by the courts under the 1939 Code.

braced redemptions of stock whether there was a corporate contraction or not, but because of the more limited scope of the term "partial liquidation" under the 1954 Code, it may be that the exemption no longer applies to $\$ 302$ (a) redemptions. See p. 53 infra. On the other hand, the punitive treatment of collapsible corporations applies to distributions in partial liquidation, but possibly not to $\$ 302$ (a) redemptions. T.D. 6152, 26 C.F.R. $\$ 1.341-1$ (1955), refers to gain from the "actual" sale or exchange of stock of a collapsible corporation, permitting the inference that a $\$ 302$ (a) redemption is not reached by $\$ 341(a)(1)$.

See T.D. 6152, 26 C.F.R. $\$ 1.302-1$ (b) (1955) as to "excess" distributions in connection with partial liquidations.

24. For problems in determining the adjusted basis of the redeemed stock, see pp. 51-53 infra.

25 . Although $\$ 346$ is captioned as defining partial liquidation, strictly speaking it simply provides that a distribution "shall be treated as in partial liquidation" under stated circumstances. However, the Regulations state: "This section [ $\$ 346]$ defines a partial liquidation." T.D. 6152, 26 C.F.R. \$1.346-1(a) (1955).

26. See Chommic, supra note 23; Oberndorfer, Partial Liquidations, N.Y.U. 13 Ta INST. ON FED. TAx. 637 (1955); Silverstein, Stockholder Gains and Losses on Partial Liquidations, N.Y.U. 14th INST. ON FED. TAX. 707 (1956).

27. INT. REv. CODE OF 1954, \$ 346(a)(1).

28. Id. $\$ 346$ (a) (2).

29. SeNATE REPORT 49 , quoted at p. 17 sispra. 
3) A distribution that terminates one of two or more active businesses engaged in by the distributing corporation. ${ }^{30}$ This category of partial liquidations was created by the 1954 Code; it is a type of corporate contraction that is ipso facto to be treated as a partial liquidation, without reference to the vague criteria of the corporate contraction concept.

These three categories of partial liquidations will be dealt with in turn.

\section{One of a Series of Distributions in Complete Liquidation: Section 346(a)( $(x)$}

Section $346(\mathrm{a})(\mathrm{I})$ provides that a distribution shall be treated as a partial liquidation of a corporation if it is one of a series of distributions in redemption of all of the stock of the corporation pursuant to a plan. The relationship of this provision to section $33 \mathrm{I}(\mathrm{a})(\mathrm{I})$, providing that amounts distributed in complete liquidation of a corporation shall be treated like the proceeds of a sale of the stock, is not clear. If a complete liquidation is consummated by a series of interim distributions without the surrender of any stock until the final distribution is made, the shareholder applies the distributions against the total basis of his stock and recognizes gain only when his basis for all the shares has been fully recovered. ${ }^{31}$ The problem of reconciling sections $346(\mathrm{a})$ and $33 \mathrm{I}(\mathrm{a})(\mathrm{I})$ arises if each interim distribution in the process of complete liquidation is accompanied by a redemption of an appropriate number of shares. There is authority for treating such a series of distributions as the equivalent of a complete liquidation, so that gain would be recognized only when the shareholder's total basis for all his shares had been recovered. ${ }^{32}$ Another approach, however, would be to

30. INT. Rev. CODE OF 1954, § 346(b).

31. Arthur Letts, 30 B.T.A. 800 (1934), affd on other grounds, 84 F.2d 760 (9th Cir. 1936). Unlike gain, loss is computed and recognized only when the final distribution is received, unless the amount of the loss can be accurately determined at an earlier time. Commissioner v. Winthrop, 98 F.2d 74 (2d Cir. 1938); G.C.M. 21966, 1940-1 CuM. BULL. 130. According to Norman Cooledge, 40 B.T.A. 110 (1939), gain or loss is to be computed separately on each block of stock held by the shareholder, rather than on the aggregate basis of all shares, so that both long- and short-term gains and losses may be realized on the liquidation.

32. See Florence M. Quinn, 35 B.T.A. 412 (1937), rejecting "the idea that in a continued process of complete liquidation a single distribution, which may if isolated answer the statutory description of a 'partial liquidation,' may be separately treated." Id. at 414. The effect of the Quinn case, according to Karl G. Von Platen, $12 \mathrm{CCH}$ Tax Ct. Mem. 657 (1953), is that "a corporate distribution made in the process of a complete liquidation must be applied against the aggregate basis of all the stockholder's shares, notwithstanding 
treat each partial liquidation as a separate transaction, computing gain or loss each time by subtracting the basis of the redeemed shares from the value of the interim distribution. ${ }^{38}$

\section{Distribution Not Essentially Equivalent to a Dividend: Section $346(a)(2)$}

A distribution is to be treated as in partial liquidation of a corporation under section $346(a)(2)$ if it (a) "is not essentially equivalent to a dividend," $(b)$ is in redemption of a part of the stock of the corporation pursuant to a plan and (c) occurs within the taxable year in which the plan is adopted or within the succeeding taxable year. The first of these requirements invokes the "corporate contraction" doctrine and poses some troublesome problems; the second and third requirements are formal in nature and should ordinarily be easily satisfied.

a) Equivalence to a Dividend. The language of this part of section $346(\mathrm{a})(2)$ echoes the phraseology of section $\operatorname{II}_{5}(\mathrm{~g})$ of the I939 Code, ${ }^{34}$ though it is somewhat less elaborate. It clearly carries

his contemporaneous surrender of some of his shares in connection with the distribution." Id. at 660 .

A combination of the theory of the Quinn case with the theory of Norman Cooledge, supra note 31 , raises some problems. Assume $A$ owns all the stock of Corporation $X$, one block of 50 shares having been acquired in 1954 at a total cost of $\$ 50,000$ and another block of 50 having been acquired in June 1955, at a total cost of $\$ 10,000$. The corporation adopts a plan of complete liquidation in October 1955 , distributes $\$ 80,000$ to $A$ at that time in exchange for 40 shares of stock (20 from each block) and makes a final distribution of $\$ 120,000$ in 1956 in exchange for the 60 remaining shares. Under the Quinn case, $\$ 20,000$ of gain would be recognized in 1955 , i.e., the excess of the total amount received in $1955(\$ 80,000)$ over the aggregate basis for the 100 shares $(\$ 60,000)$, and $\$ 120,000$ of gain would be recognized in 1956 . But if the approach of the Cooledge case were adopted, the 1955 distribution would produce a long-term gain of $\$ 20,000$ ( $\$ 40,000$ received for 20 shares of 1954 stock costing $\$ 20,000$ ) and a short-term gain of $\$ 36,000$ ( $\$ 40,000$ received for 20 shares of 1955 stock costing $\$ 4,000$ ), while the 1956 distribution would produce a long-term gain of $\$ 84,000$ ( $\$ 120,000$ received for 30 shares of 1954 stock costing $\$ 30,000$ and 30 shares of 1955 stock costing $\$ 6,000$ ).

Under the Quinn case, it is necessary to determine when a partial liquidation is only a step toward a complete liquidation and when it stands on its own feet as a separate transaction. See National Investors Corp. v. Hoey, 52 F. Supp. 556 (S.D.N.Y. 1943), rev'd, 144 F.2d 466 (2d Cir. 1944); Karl Von Platen, supra; T. T. Word Supply Co., 41 B.T.A. 965, 980 (1940); John B. Williams, 28 B.T.A. 1279 (1933). Partial liquidations falling into the latter category could claim capital gain or loss treatment, under the 1954 Code, only if they qualify under $\$ 346(\mathrm{a})(2)$.

33. In Courtenay D. Allington, 31 B.T.A. 421 (1934), a partial liquidation that, according to the findings of facts, was a step in a complete liquidation, was treated as a separate transaction for computation of gain. The only issue discussed by the court was whether the basis of the shares surrendered at the time of the first liquidating distribution should be computed under the "first-in-first-out" rule of the Regulations. But the computations in the findings of fact show that the Quinn rule, requiring the distribution to be applied first against the shareholder's total basis for all his shares, was not followed. See also National Investors Corp. v. Hoey, supra note 32; J. Paul McDaniel, 25 T.C. 276 (1955); Estate of Charles Fearon, 16 T.C. 385 (1951); Friedman, Points to Be Considered in Liquidating a Corporation, N.Y.U. 5TH INST. ON Fed. TAx. 747, 764-72 (1947).

34. See pp. 14-15 supra. 
forward to some degree the "corporate contraction" doctrine that was developed under old section $\operatorname{II}_{5}(\mathrm{~g})$. But what is less clear is whether section 346 (a) (2) can be satisfied only by distributions resulting from corporate contractions. The statute itself sheds no light on the subject. The Senate Report at one point flatly implies that section $346(a)$ is concerned only with redemptions that "terminate a part of the business of the corporation," 35 though at other points it seems to regard corporate contractions as the principal, but not necessarily the sole, instance of partial liquidation. ${ }^{38}$ The emphasis on the nature of the assets distributed, as a test of partial liquidation, ${ }^{37}$ leaves little room for distributions that do not result from corporate contractions, since only in the case of corporate contractions has it been thought that the nature of the distributed assets was an important element in determining whether the distribution was essentially equivalent to a dividend. It is not likely, therefore, that section $346(a)$ (2) will be satisfied by distributions that do not reflect a corporate contraction. ${ }^{38}$

According to the Senate Report, the definition of partial liquidation of the 1954 Code primarily "involves the concept of "corporate contraction' as developed under existing law." ${ }^{39}$ At another point the Report states:

The general language of the proposed draft would include within the definition of a partial liquidation the type of cases involving the contraction of the corporate business. Such as for example, cases which hold that if the entire floor of a factory is destroyed by fire, the insurance pro. ceeds received may be distributed pro rata to the shareholders without the imposition of $\mathbf{a}$ tax at the rates applicable to the distribution of a dividend, if the corporation no longer continues its operations to the same extent maintained by the destroyed facility. Voluntary bona fide contraction of

35. SENATE REPORT 255. In referring to $\$ 306(\mathrm{~b})(2)$, the Senate Report states: "In the case of a partial liquidation your committee contemplates a contraction of the corporate business ...." Id. at 243 .

36. "Primarily, this definition [\$346(a)] involves the concept of "corporate contraction' as developed under existing law." Id. at 262. See also id. at 49, quoted at p. 17 infra.

37. Ibid.

38. One commentator argues that one of the most convincing arguments against limiting $\S 346$ (a) (2) to corporate contractions is the use of the term "primarily" in the statement in the Senate Report, quoted in note 36 supra. Chommie, Section 346(a) (2): The Contraction Theory, 11 TAX L. REV. 407, 426 (1956). But the phrase "primarily" refers to the entire definition of $\S 346$ (a), not merely to that part in $\$ 346(a)(2)$. The "secondary implication" which Chommie seeks could very well be the type of partial liquidation defined by $\$ 346(\mathrm{a})(1)$, leaving corporate contractions as the sole basis for applying $\$ 346$ (a)(2). Another writer takes a more liberal view of the scope of \$346(a)(2), though recognizing that the Senate Report is less liberal than he. Cohen, Redemptions of Stock Under the Internal Revenue Code of 1954, 103 U. PA. L. Rev. 739, 768-69 (1955), 39. Senate Report 262. 
the corporate business may of course also qualify to the same extent as under existing law. ${ }^{40}$

The corporate contraction doctrine under the 1939 Code embraced not only the overworked destruction-by-fire case, ${ }^{41}$ but others where the reason for capital gain or loss treatment was even more obscure. ${ }^{42}$ Redemptions because a reserve for expansion was no longer

40. Ibid.

41. Joseph Imler, 11 T.C. 836 (1948).

42. The author has previously expressed his belief that the "corporate contraction" standard is not a legitimate test for determining whether a redemption is substantially equivalent to a dividend:

'Tiven if one assumes that a 'business purpose' test has a proper place in the interpretation of section $115(\mathrm{~g})$, it is highly questionable that the standard of 'legitimate shrinkage' has any economic validity. Courts are impressed with the discontinuance of a part of the business. But what if we have a business which has accumulated a surplus in expectation of an expansion which, for some reason, never occurs? When this corporation distributes the surplus, the stockholders probably will not be protected by the shield of legitimate shrinkage. But in both cases the economic decision made by the directors was essentially the same. They decided that capital was no longer required for the needs of the business and could be distributed among the stockholders through a redemption of capital stock. In one instance the capital had been used for an activity that was being curtailed. In the other, it was capital that had been saved for an activity which never took place. It is hard to understand why one distribution represents a more 'legitimate shrinkage' than the other or exhibits a more valid business purpose.

"And the "legitimate shrinkage" concept becomes more meaningless when viewed as a standard of taxation under section $115(\mathrm{~g})$. That section is concerned with taxing distributions that are 'essentially equivalent' to dividends. No stockholder can escape paying a tax under section 115(a), the section which defines dividends, because the distribution represented a 'legitimate shrinkage' of the corporation's activities. A distribution is a dividend under section $115(\mathrm{a})$ when earnings and profits are separated from the corporation and distributed to the shareholders without altering their relative ownership interests. If the same result is achieved as a result of a redemption of stock, it should be taxed as a dividend. Obviously, if we are looking to see whether there has been a distribution of assets without a change in proportionate ownership, it is immaterial whether the distribution was caused by a legitimate shrinkage or by boom-year profits."

Bittker \& Redlich, Corporate Liquidations and the Income Tax, 5 Tax L. REv. 437, 472-73 (1950).

"It is very doubtful if the contours of a contraction test can be prescribed with any measure of success. But even if we assume that we can define 'contraction,' what is its relevance? By hypothesis the corporation has accumulated profits and is distributing cash representing some of these profits. The corporation does not intend to conclude its existence, for the distribution is not one of a series of distributions in complete liquidation of the corporation. The shareholders remain as shareholders, their initial investment is still intact, and their relationships to the cosporation and each other have not been altered. In such a setting, the distribution of cash should be treated for what it is-a distribution of profits. The activity at the corporate level which produced the cash and the motivation behind its distribution are not matters which should affect this conclusion.

"In this regard, we should not be moved by the emotional case in which cash results from an 'involuntary conversion' of a part of a business, as where a branch activity is destroyed by fire and instead of rebuilding the activity the corporation distributes the insurance proceeds. Such proceeds are simply cash profits being distributed. The fire unexpectedly forced the directors to make a decision involving the cessation of the activity. An unexpected but tempting offer to purchase the activity equally would have prompted a directors' meeting.

"We may also dismiss the argument based on rewriting history-viz., the corporation originally could have been two corporations, each operating a part of the busi- 
required, or because a shift in the scale or nature of the corporation's operations had caused a decline in its need for working capital, or because property was being distributed to protect it from the claims of corporate creditors or because an unprofitable department had been liquidated-all have sometimes successfully claimed the mantle of corporate contraction. ${ }^{43}$ It may be going too far to say that under the I939 Code the royal road to capital gain treatment for cash distributions to shareholders was to find some immediate or potential corporate use for its earnings and profits and wait for a plausible excuse for abandoning that use, but the cases were gradually beating at least a rough trail for astute taxpayers to follow. ${ }^{44}$

ness, so that a later sale of the assets of one of the corporations would have resulted in its complete liquidation and hence capital gain treatment. Usually the business of a corporation simply expands out of accumulated earnings, a pattern which does not permit the separate incorporation hypothesis. Moreover, even if the situation would have accommodated two corporations at the outset, the shareholders did choose a different routc. And the activities of a single corporation over the years are different from the relationships and activities of several corporations over the same period of time. There is, therefore, no justification for discovering hypothetical twins at the last minute."

Cohen, A Technical Revision of the Federal Income Tax Treatment of Corporate Distributions to Shareholders, 52 CoLUM. L. Rev. 1, 37-38 (1952).

43. Reserves for expansion: Commissioner v. Champion, 78 F.2d 513 (6th Cir. 1935); S. A. Upham, 4 T.C. 1120 (1945). Contra: McGuire v. Commissioner, 84 F.2d 431 (7th Cir. 1936). Decline in working capital needs: Commissioner v. Quackenbos, 78 F.2d 156 (2d Cir. 1935); Clarence R. O'Brion, $10 \mathrm{CCH}$ Tax Ct. Mem. 1122 (1951); Edwin L. Jones, P-H 1942 T.C. Mem. Dec. If 51373; John P. Elton, 47 B.T.A. 111 (1942). Contra: Dunton v. Clauson, 67 F. Supp. 839 (S.D. Me. 1946). Protection against creditors: Commissioner v. Sullivan, 210 F.2d 607 (5th Cir. 1954); see also L. M. Lockhart, 8 'T.C. 436 (1947). Liquidation of department: Commissioner v. Babson, 70 F.2d 304 (7th Cir. 1934); Heber Scoweroft Inv. Co., 4 CCH Tax Ct. Mem. 755 (1945).

Because the courts rarely if ever find it necessary to base a decision on a single factor, it cannot be said with assurance that the element of contraction was the sole foundation for any of the foregoing decisions, though it appears to have been at least persuasive, if not the turning point, in all. It is entirely possible, however, that some of the earlier cases would not pass the more rigorous judicial examination that has been common recently. See Chommie, supra note 38 , at 418 .

44. See the warning in Edward L. Kraus, 6 T.C. 105 (1946), involving a manufacturing company which sold a portfolio of securities and redeemed some of its stock with the proceeds.

"The argument is made that an investment business was conducted . . . to support the contention that there was a partial liquidation of the company when the securities were sold. But the liquidation of assets of the character we have here does not necessarily result in a liquidation of a "business,' nor does the fact that the $\$ 150$,000 which was distributed was most of the proceeds from the sale of securities stamp them as liquidating distributions. ... If the securities represented the investment of accumulated profits, as we are compelled to conclude, the sales of the securities in 1940 operated to return to the company a fund of accumulated profits."

1d. at 120-21. See also Hyman v. Helvering, 71 F.2d 342 (D.C. Cir. 1934).

"And so also if a corporation invests earnings in plant and equipment, which, in later years, in a policy of contraction of business activities, it decides to sell and to divide the proceeds among its shareholders, the distribution is none the less a dividend, though the device of cancelling some of the outstanding shares be adopted as a Id. at 344 . method of accomplishing the end sought."

These cases are extreme instances of judicial alertmess to abuse of the corporate contraction doctrine, and it cannot be said that they reflect the customary attitude in this area. 
Notwithstanding several references to existing law, the draftsmen of section $346(\mathrm{a})$ (2) gave at least two indications that the preI954 law of corporate contractions was not ratified in every respect. The Senate Report states flatly that "a distribution of a reserve for expansion is not a partial liquidation," ${ }^{45}$ thus rejecting at least some pre-I954 cases. $^{46}$ Moreover, the almost equally clear implication that section $346($ a) (2) applies only to redemptions that "terminate a part of the business of the corporation" ${ }^{\prime 47}$ is not compatible with pre-1954 cases holding that a distribution of excess working capital can qualify as a partial liquidation. ${ }^{48}$ Even in the absence of these inconsistencies between the Senate Report and pre-I954 law, it would be improper to interpret a general intention to carry forward existing law as either a blanket endorsement of every judicial decision theretofore rendered or as preventing further evolutionary developments in what is at best an imprecise concept imposed upon very divergent sets of facts. In this connection, it is worthy of note that the case of Joseph W. Imler, ${ }^{40}$ explicitly described and approved by the Senate Report, ${ }^{50}$ states:

The issue here raised presents a question of fact depending on the circumstances of the particular case. . . . No sole or universally applicable test can be laid down. . . . Though decided cases are not controlling, they are helpful as indicating what elements have been considered important, viz., the presence or absence of a real business purpose, the motives of the corporation at the time of distribution, the size of the corporate surplus, the past dividend policy, and the presence of any special circumstance relating to the distribution. ${ }^{51}$

The existence of conflicting decisions and inconsistent approaches in the pre-x954 case law makes judicial choices in the future unavoidable. The "corporate contraction" doctrine, then must be viewed as an organic concept, not as a frozen body of rules. $^{52}$

45. SeNATE REPORT 262. See T.D. 6152, 26 C.F.R. \$ 1.346-1(a) (1955).

46. Commissioner v. Champion, 78 F.2d 513 (6th Cir. 1935); Samuel A. Upham, 4 T.C. 1120 (1945).

47. SenATE REPORT 225, 243.

48. Commissioner v. Quackenbos, 78 F.2d 156 (2d Cir. 1935); Clarence R. O'Brion, 10 CCH Tax Ct. Mem. 1122 (1951); Edwin L. Jones, P-F 1942 T.C. Mem. Dec. II 51373 ; John P. Elton, 47 B.T.A. 111 (1942).

49. 11 T.C. 836 (1948).

50. SENATE REPORT 262.

51. Joseph W. Imler, 11 T.C. 836, 840 (1948). For other examples, see Estate of Charles D. Chandler, 22 T.C. 1158, 1166 (1954) ("a contraction of business per se does not render section 115 [g] inapplicable"); L. M. Lockhart, 8 T.C. 436 (1947).

52. See Chommie, Section 346(a)(2): The Contraction Theory, 11 TAx L. REv. 407, 418 (1956), reviewing many cases and pointing out that some of the earlier corporate contraction cases might have been decided differently had they come up in recent years. 
b) Redemption Pursuant to a Plan. Section $346(a)$ (2) requires a "redemption" of stock. Under the pre-I954 law, some courts held that reacquired stock that was held in the treasury had not been "cancelled or redeemed." ${ }^{3}$ Section $3^{\mathrm{I}} \mathrm{T}$ (b) defines "redemption" as a reacquisition of stock by a corporation from a shareholder in exchange for property, whether the stock is thereafter cancelled, retired or held as treasury stock. This definition, which prevents form from triumphing over substance, does not technically apply to section 346 , though probably this was an oversight. ${ }^{54}$

Another problem in this area is whether a distribution accompanying a reduction in the par or stated value of stock constitutes a redemption, even though no stock is surrendered by the shareholders. The proposed Regulations stated that such a distribution is a redemption, ${ }^{55}$ but this announcement was omitted from the final Regulations. Such a distribution was not equivalent to a redemption under the r939 Code ${ }^{56}$ and nothing in the 1954 Code suggests that a different rule should be applied in the future. ${ }^{57}$

Section 346(a) requires a redemption "pursuant to a plan." The term "plan" is not defined in either the Code or the Regulations. No doubt an informal plan will suffice, as in other areas where a

53. Commissioner v. Snite, 177 F.2d 819 (7th Cir. 1949); Alpers v. Commissioner, 126 F.2d 58 (2d Cir. 1942). Contra: Keefe v. Cote, 213 F.2d 651 (1st Cir. 1954); Wall v. United States, 164 F.2d 462 (4th Cir. 1947). Dictum contra, Smith v. United States, 131 Ct. Cl. 748, 130 F. Supp. 586 (1955). An intermediate position, treating treasury shares as cancelled or redeemed where there was no intention to reissue them, was apparently approved in Boyle v. Commissioner, 187 F.2d 557 (3d Cir.), cert. denied, 342 U.S. 817 (1951).

54. Since the definition in $\$ 317$ (b) is "for purposes of this part" technically it applies only to part I of the subchapter. Section 346 is in part II. It is possible that the Commissioner would argue that holding reacquired shares in the treasury, at least if they were to be reissued soon, is inconsistent with a claimed corporate contraction. If stock held in the treasury has not been "redeemed," the transaction could not claim the protection of $\S 331$ (a)(2). It would then have to be tested by the standards of $\S 302$, under which the corporate contraction would be irrelevant.

55. Proposed Regulations, §1.317-2, 19 FED. REG. 8254 (1954).

56. Sheehan v. Dana, 163 F.2d 316, 173 A.L.R. 684 (8th Cir. 1947); Beretta v. Commissioner, 141 F.2d 452 (5th Cir.), cert. denied, 323 U.S. 720 (1944).

What if a corporation that could engage in a corporate contraction under $\S 346$ (a)(2) by redeeming part of its stock chooses to distribute the unwanted assets in two steps, the first distribution being in reduction of the par value of one class of stock, and the second distribution being in redemption of the same class? Under the 1939 Code the first distribution, as well as the second, might have qualified as a partial liquidation, on the ground that it was "one of a series of distributions in complete cancellation or redemption of all or a portion of its stock." Int. Rev. Code of $1939 \$ 115(\mathrm{i}), 53$ STAт. 48. [Emphasis added.] See R. D. Merrill Co., 4 T.C. 955, 967-68 (1945). But the 1954 Code does not lend itself so easily to the same interpretation. Section 346(a) (1) permits a compleze liquidation to be effected by a series of interim distributions, but $\$ 346(a)(2)$ seems to contemplate that each distribution in the process of partial liquidation will be accompanied by a redemption of stock.

57. See Senate Report 252. 
corporate adjustment must occur under a plan, but careful counsel will not trust to luck.

c) Distribution in the Year the Plan Is Adopted or Within the Succeeding Year. Since neither the Code nor the Regulations defines the term "plan," it is not surprising that neither states how the time of its adoption should be determined. No doubt the time will ordinarily begin to run from the formal action by the shareholders authorizing the redemption, but the Commissioner might be justified on occasion in determining that the plan was adopted by informal action at an earlier date and in disqualifying a distribution as too late under section $346(a)(2) .^{58}$

\section{Termination of a Business: Section 346(b)}

The shareholders need not concern themselves with the vagaries of the "corporate contraction" concept if the distribution meets the requirements of section 346 (b), relating to a distribution in termination of an active business by a corporation that is engaged in two or more active businesses. ${ }^{59}$ This provision has no counterpart in the 1939 Code. To qualify under section $346(\mathrm{~b})$, the following requirements must be met:

I) The distribution must be attributable to the corporation's ceasing to conduct, or must consist of the assets of, a trade or business;

2) Immediately after the distribution, the distributing corporation must be actively engaged in a trade or business;

3) Both the retained trade or business and the one that was distributed (or that gave rise to the distribution) must have been actively conducted (though not necessarily by the distributing cor-

58. See T.D. 6152, 26 C.F.R. \$ 1.337-2(b) (1955).

59. "[Section 346] (b) provides a description of one kind of distribution which will be considered as being in partial liquidation. Paragraphs (1) and (2) contemplate that the distributing corporation must be engaged in the active conduct of at least 2 businesses which have been actively conducted (whether or not by it) for the 5-year period ending on the date of the distribution. Neither of such businesses may have been acquired within such period in a transaction in which gain or loss was recognized in whole or in part. Thus, a qualifying business may not have been acquired by purchase or a corporate reorganization where so-called 'boot' was present. If these requirements are met, one of the active businesses may be distributed in kind (or the proceeds of salc of such a business may be distributed) as long as the corporation immediately after the distribution is engaged in the active conduct of a business as described above. The determination of whether the requirements of subsection (b) [of $\$ 346$ ] have been met shall be made without regard to whether the distribution is pro rata among the shareholders of the corporation."

SENATE REPORT 262. 
poration) throughout the five-year period before the distribution; and

4) Neither of the trades or businesses may have been acquired by the distributing corporation within the five-year period in a transaction in which gain or loss was recognized in whole or in part.

This battery of requirements may be understood more easily if their purpose is known. Accepting the "corporate contraction" doctrine as an appropriate test, the draftsmen wanted to create an area in which capital gains treatment would be assured without the necessity of justifying each distribution, case by case, under the vague standards of the courts. ${ }^{80}$ They thought that if a corporation with two or more businesses wished to distribute one of them, the distribution should be treated as a partial liquidation. At the same time, they did not want to open an easy route to tax avoidance, and they recognized the possibility that a closely held corporation could accumulate its earnings and profits, invest its surplus cash in assets that the shareholders would like to hold as individuals, and then go through the form of a corporate contraction by distributing the newly acquired assets and retaining the business assets. ${ }^{61}$ The requirement in section $346(\mathrm{~b})$ of active conduct of a trade or business will prevent an evasion of the tax on dividends by a corporate purchase and subsequent distribution of investment securities or real estate in redemption of part of the stock of the corporation, and it will also probably prevent the distribution of a factory, a patent or similar assets by the corporation. ${ }^{62}$ The five-year rule, coupled with the prohibition on the acquisition of either of the trades or businesses by purchase, ${ }^{63}$ will prevent the corporation from accumu-

60. The House Bill had limited the concept of partial liquidation to distributions meeting requirements similar to those of $\S 346(\mathrm{~b})$, but the draftsmen of the Senate Bill added the more general language of $\$ 346$ (a)(2). See H.R. 8300, 83d Cong., 2d Sess. $\$ 336$ (a) (1954).

61. See Edward L. Kraus, 6 T.C. 105 (1946)

62. T.D. 6152,26 C.F.R. $\$ 1.346-1$ (c) (1955), provides "the term "active conduct of a trade or business' shall have the same meaning in this section" as in T.D. 6152,26 C.F.R. $\$ 1.355-1$ (c) (1955). On the effect of changes in the business, see H.R. REP. No. $2543,83 \mathrm{~d}$ Cong., $2 \mathrm{~d}$ Sess. 38 (1954).

For rulings under $\S 346(\mathrm{~b})$ and $\S 355$ (b), see Rev. Rul. 56-513, 1956 INT. Rev. BuLx. No. 42, at 16; Rev. Rul. 56-512, 1956 INT. Rev. Burl. No. 42, at 15; Rev. Rul. 56-450, 1956 INt. Rev. Buzl. No. 37, at 15; Rev. Rule 56-287, 1956 INt. Rev. Bull. No. 26, at 60. See also Rev. Rul. 56-344, 1956 INT. Rev. Bull. No. 30, at 9; Rev. Rul. 56-227, 1956 INT. REv. BuLl. No. 22, at 8.

63. The prohibition on acquiring the trade or business during the 5-year period "in a transaction in which gain or loss was recognized in whole or in part" was obviously intended to apply to transactions in which the transferor recognized gain or loss, even though the transferee did not. See the reference to acquisition by "purchase" in the extract 
lating its earnings and profits and investing its surplus in a farm, ranch or similar property that the shareholders would otherwise have acquired with taxable dividends, with a view to a prompt distribution in partial liquidation under section $346(\mathrm{~b})$. It will not, however, prevent a similar plan for avoidance of the dividend tax if the shareholders are patient. After the farm or ranch has been held for five years, assuming its operation constitutes the "active conduct of a trade or business," its distribution can qualify under section $346(\mathrm{~b})$, with a possible exception for transactions that can be characterized as shams.

Although the statute does not explicitly require a plan of redemption under section $346(\mathrm{~b})$, or even a redemption of stock, the Regulations take the position that the distribution under section 346 (b) must occur in the taxable year in which the plan is adopted or within the following taxable year. ${ }^{65}$

\section{STOCK REDEMPTIONS}

If a redemption of stock does not meet the qualifications of a partial liquidation, it may nevertheless be accorded capital gain or loss treatment by section $302 .{ }^{66}$ Section 302 (a) provides that a redemption of stock shall be treated as a distribution in part or full payment in exchange for the stock if it falls into any one of four categories:

from SeNATE REPORT 262, quoted at note 59 sutpra. Moreover, acquisition by purchase is probably prohibited even though gain or loss was not recognized because the price paid happens to be exactly equal to the adjusted basis of the acquired trade or business. The Senate Report's reference to acquisition by purchase, as well as the purpose of the section, also indicate that the purchase (within the 5-year period) of a trade or business from a corporation that recognizes no gain or loss on the sale under $\$ 337$ should not qualify. It would seem that gain or loss is recognized in such a transaction, within the meaning of $\S 346(b)$, by the shareholders of the selling corporation on its liquidation, since the sale under $\$ 337$ and the liquidation of the selling corporation constitute an integrated transaction. A more sophisticated variation on this theme would be a purchase by the distributing corporation of the stock of a second corporation, followed by a sale by the second corporation of its trade or business to the first corporation under $\$ 337$. Here the liquidation of the second corporation would not produce gain or loss to anyone if the liquidating proceeds were equal to the price paid by the distributing corporation for the stock of the second corporation. But the acquisition of the stock of the second corporation would have produced gain or loss to its original shareholders, and this could be regarded as a "transaction in which gain or loss was recognized in whole or in part" within the meaning of $\S 346$ (b). It should be noted, however, that $\$ 346$ (b) is not as explicit as $\S 355$ (b) (2), which, in dealing with a similar problem, prohibits not only the acquisition of a trade or business during the 5 -year period but also the acquisition of a corporation conducting the trade or business. See H.R. REP. No. 2543, 83 Cong., 2d Sess. 37-38 (1954).

64. A redemption is probably implicitly required by $\S 331$ (a)(2).

65. T.D. 6152, 26 C.F.R. $\$ 1.346-1$ (b) (1955).

66. See note 23 supra. 
I) A complete redemption of all of the shareholder's stock under section 302 (b) (3).

2) A substantially disproportionate redemption of the shareholder's stock under section 302 (b) (2).

3) A redemption that is not essentially equivalent to a dividend under section $302(\mathrm{~b})$ (I).

4) A redemption of the stock of certain railroad corporations under section 302 (b) (4).

By virtue of section 302(d), a redemption that does not fall into one of the foregoing categories is treated as a distribution under section 3 or and will therefore constitute a dividend includable in gross income to the extent of current and post-rgr 3 earnings and profits, and a return of capital to the extent of the excess. ${ }^{67}$ Only the first three of the above categories will be discussed below.

\section{Termination of a Shareholder's Entire Interest: \\ Section 302(b) (3)}

Section 302 (b) (3) provides that a redemption shall be treated as a sale if it "is in complete redemption of all of the stock of the corporation owned by the shareholder." If a corporation is owned by $A$ and $B$, two unrelated persons, a redemption of all of the stock of either $A$ or $B$ will qualify under section 302(b) (3). A redemption of this type was similarly treated as a sale, rather than a dividend, under pre-r954 law. ${ }^{\text {. }}$

a) The Attribution Rules. But what if shareholders $A$ and $B$ are related? Section 302 (c) provides that in determining the ownership of stock under section 302, the constructive ownership rules of section $3 \mathrm{I} 8$ (a) shall apply. ${ }^{69}$ By virtue of these rules an

67. See note 103 infra.

68. See note 13 supra.

69. Taxpayers are put into the same boat as their relatives by many sections of the 1954 Code, but a close relative for one purpose is not necessarily close enough for another. By an insight into the emotional ties of the contemporary family that is denied to most of us, the draftsmen of the Code have decided that a taxpayer shall be charged with his brother's stock by $\S 267$, in order to disallow losses on the sale of property to his brother's corporation, but not by $\S 318$ in order to determine whether a redemption terminates his stock interest under $\S 302$ (b) (3). And they have decided that he shall be charged with his brother-in-law's stock by $\$ 341$ (d) in computing gain on the sale of stock in a collapsible corporation but not by $\$ 544(\mathrm{a})$ in characterizing the same corporation as a personal holding company. For a tabulation of unwanted kinsmen, see Frank, Know Thy Kin, 33 TANEs 409 (1955), to which could be added the variations on \$544(a) introduced by $\$ 341$ (d).

The 1939 Code did not explicitly attribute stock owned by one person to another in the application of $\$ 115(\mathrm{~g})$. In 1951 the Treasury Department announced a proposal to amend the Regulations under $\$ 115(\mathrm{~g})$ (see note 13 supra) to provide that the redemption of all of the stock of a particular shareholder would "generally" not be subject to $\$ 115(\mathrm{~g})$, 
individual is "considered as owning" any stock owned by certain members of his family (his spouse, children, grandchildren and parents), owned by partnerships, estates, certain trusts and certain corporations in which he is financially interested or subject to any option held by him. If $B$ is $A$ 's son or $A$ 's wholly owned corporation, $B$ 's stock would be imputed to $A$ (and vice versa) under section 3I8(a). A redemption of all the stock actually owned by either $A$ or $B$ would not qualify under section 302(b) (3). In the case of "family" corporations, the constructive ownership rules will frequently prevent a redemption of all the stock actually owned by one shareholder from qualifying under section 302 (b) (3), especially because there may be more than one link in the chain of imputed ownership.

b) Waiver of the Family Attribution Rules. But the constructive ownership rules of section 3r8(a) are not inescapable. Section 302 (c) (2) provides that the family attribution rules shall not apply to a shareholder whose stock is redeemed if immediately after the distribution he has no "interest" in the corporation (including an interest as officer, director or employee), other than an interest as a creditor, and if he does not acquire any such interest (other than stock acquired by bequest or inheritance) ${ }^{70}$ within ten years from the date of the distribution. ${ }^{71}$

This waiver of the family attribution rules will clear the way to a redemption under section 302(b) (3), if the distributee is willing and able to forgo any interest in the corporation (except an interest as a creditor and an interest arising from the acquisition of stock by bequest or inheritance) for a period of ten years. The theory of the family attribution rules and of their waiver may be

but that "where such shareholder is closely related to remaining shareholders, that factor will be considered along with all other circumstances of the case in determining whether the distribution is essentially equivalent to a dividend." 16 FED. REG. 10312 (1951). The proposed amendment was withdrawn after the 1954 Code was enacted. 19 FED. REg. 7159 (1954). Even without the aid of the regulations, both the courts and the Internal Revenue Service have at times regarded the relationship between a shareholder whose stock was redeemed and the remaining shareholders as significant. See Irwin G. Lukens, 26 T.C. No. 113 (July 31, 1956); William H. Grimditch, 37 B.T.A. 402, 412 (1938); Rev. Rul. 55-547, 1955-2 Cum. Bull. 571; Rev. Rul. 55-373, 1955-1 Cum. Bull. 363. But see Estate of Ira F. Searle, 9 CCH Tax Ct. Mem. 957 (1950).

70. The phrase "bequest, devise, or inheritance" under Int. Rev. Code of 1939 $\$ 113(2)(5), 53$ STAT. 41, prescribing the basis of property so acquired, excluded several types of acquisition that were similar to bequests.

71. INT. REv. CODE of 1954, $\$ 302$ (c)(2)(A); T.D. 6152, 26 C.F.R. $\$ 1.302-4(\mathrm{a})$,

(b) (1955). A taxpayer who relies on section $302(\mathrm{c})(2)$ for a waiver of the family attribution rules must agree to notify the Treasury if he acquires any such interest in the corporation, and the periods of limitation on assessment and collection of any deficiency resulting from the acquisition of an interest are appropriately extended. 
stated in this fashion: a redemption of all the stock of a shareholder is properly treated as a sale because it terminates his interest in the corporation as effectively as a sale to a third person. The analogy is not appropriate, however, if after the redemption stock is owned by a member of the ex-shareholder's immediate family. It is suffciently possible that he will thereby continue his interest in the corporation (without the interference from the outside that might have resulted if he had sold his stock to a third person) that an attribution of his relative's shares to him is a reasonable rule of thumb. If, however, he is willing to give up for a ten-year period any interest in the corporation, except those interests specifically excluded, it is reasonable to waive the family attribution rules and treat the redemption as a sale.

It should be noted that section 302 (c) (2) waives only the family attribution rules. There is no escape from the rules that attribute stock to the taxpayer if he has a beneficial or indirect interest in it through partnerships, estates, certain trusts or certain corporations, or if he has an option to buy it. Moreover, stock held by a nominee would undoubtedly be treated as owned by the principal without reliance upon section $3 \mathrm{I} 8$, even if the nominee were not a relative of the true owner.

The conditions attached by section 302 (c) (2) to a waiver of the family attribution rules are not without some ambiguities. The prohibition of "an interest [in the corporation] as officer, director, or employee" could be construed to bar employment coupled with profit-sharing or a similar financial stake "in" the corporation, rather than any and all employment whatsoever. But careful taxpayers would seek a ruling before assuming that some types of employment are permissible. ${ }^{72}$ The permission to retain or acquire an interest as a creditor will be especially important if the shareholder

72. Section 302 (c) (2) (A) (i) does not explicitly prohibit employment or office-holding per se; it speaks of "an interest as officer, director, or employee," and this could be interpreted to mean something more than the performance of services alone. See Rev. Rul. 54-408, 1954-2 Cun. ButL. 165, implying that a majority shareholder whose stock was redeemed had ceased "to be interested in the affairs of the corporation" within the meaning of the old regulations (sce note 13 supra), even though he remained in the employ of the corporation for four years to train new employees. On the other hand, the Commissioner could argue from the specific exemption of "an interest as a creditor" that the term "interest" is to be given the broadest possible construction. The Commissioner would also find some comfort in H.R. REP. No. 2543, 83d Cong., 2d Sess. 76 (1954). 'Turning from the letter to the spirit, however, the purpose of prohibiting an interest is to prevent a shareholder from ostensibly selling out but actually carrying on as before. This suggests a more discriminating construction of the term "interest," though in a doubtul case it would be more appropriate to lean toward strictness than liberality. 
wishes to sell his shares to the corporation on credit, rather than for cash. The Regulations appropriately warn against obligations "in the form of debt" that in fact give the owner a "proprietary interest, ${ }^{\prime 73}$ but the application of this principle will not be easy.

The waiver of the family ownership rule found in section 302 (c) (2) (A) is denied in certain circumstances. Before examining these conditions, which are set out in section 302 (c) (2)(B), it may be well to see an illustration of their purpose. If $A$ owns all the stock of Corporation $C$, and wishes to give his son a gift of cash, he can of course use funds that he has received as dividends from Corporation $C$, but only after they have been reported as income. If he raises the funds by causing the corporation to redeem part of his stock, the redemption will probably be taxed as a dividend. ${ }^{74}$ What about giving his son some stock in Corporation $C$ and then causing it to redeem the son's stock? If the transaction avoids the sham category, ${ }^{75} A$, Jr., could claim the shelter of section $302(\mathrm{~b})$ (3), avoiding the family attribution rules of section 3I8(a) (which if applicable would take the transaction out of section $302(\mathrm{~b})$ (3) by imputing $A$ 's unredeemed stock to $A, \mathrm{Jr}$.) by forgoing any "interest" in the corporation.

To frustrate plans of the type just described, section 302 (c)(2) (B) provides that the family attribution rules shall not be waived in either of two instances: ( $\mathrm{I}$ ) If any part of the redeemed stock were acquired, ${ }^{76}$ directly or indirectly, within the previous ten years by the distributee from a related person, ${ }^{77}$ or (2) if any related person owns stock at the time of the distribution and acquired any stock, directly or indirectly, from the distributee within the pre-

73. In contradistinction to the proposed Regulations, $\$ 1.302-4$ (d), 19 FED. REG. 8240 (1954), which prohibited obligations that were contingent upon earnings as to either principal or interest, the final Regulations permit interest to be geared to corporate earnings in some cases. T.D. 6152, 26 C.F.R. $\$ 1.302-4$ (d) (1955).

74. It would not meet the requirements of $\$ 302$ (b) (3), because only part of $A$ 's stock was redeemed, nor those of $\$ 302$ (b)(2) (see p. 42 infra), because $A$ owns more than $50 \%$ of the common stock of the corporation after the redemption; and it would probably not meet the requirements of $\S 302$ (b) (1) (see pp. 42-45 infra) unless other significant facts were present.

75. A blatant case could be treated like an anticipatory assignment of a dividend, i.e., as though the redeemed shares had been acquired by the corporation from the father, followed by a gift of the proceeds to the son. See Rhodes' Estate v. Commissioner, 131 F.2d 50 (6th Cir. 1942).

76. It is immaterial whether the acquisition was by gift or for consideration. SENATE REPORT 237.

77. That is, "a person the ownership of whose stock would (at the time of the distribution) be attributable to the distributee under section 318(a)." INT. REv. CODE OF $1954, \S 302$ (c) (2)(B)(i). It is not clear whether this embraces any person whose stock, if he owned any at the time of the distribution, would be attributable to the distributee or is limited to persons who are in fact shareholders at the time of the distribution. 
vious ten years, unless the stock so acquired is redeemed in the same transaction. ${ }^{78}$

These limitations on the waiver of the family attribution rules are not applicable under section 302 (c) (2)(B) if the acquisition in (I) above or the disposition in (2) above did not have "as one of its principal purposes the avoidance of Federal income tax." The Regulations state that a transfer "shall not be deemed to have as one of its principal purposes the avoidance of Federal income tax merely because the transferee is in a lower income tax bracket than the transferor."79 It may be, however, that a transfer to such a person for the purpose of reducing the total family income tax burden would prevent a waiver of the family attribution rules. A transfer to avoid federal estate tax does not act as a bar to a waiver of the family attribution rules.

c) Redemption Following Sale. Section 302(b)(3) requires, as we have seen, a redemption of "all of the stock of the corporation owned by the shareholder." Suppose the shareholder sells part of his stock and the corporation, by prearrangement, redeems the rest. In a celebrated pre-I954 case involving a one-man corporation, the Internal Revenue Service contended that such a redemption was a dividend to the original shareholder under section $\operatorname{II}_{5}(\mathrm{~g})$ of the 1939 Code, arguing that the redemption of part of his stock would have been a dividend if it occurred before the sale and that the result should be the same where the redemption followed the sale by prearrangement. The Court of Appeals for the Sixth Circuit held to the contrary, ${ }^{80}$ however, and the Internal Revenue Service announced that it would not continue to litigate the issue. ${ }^{81}$

78. This provision would apply, for example, if a shareholder gave some of his shares to his son and the corporation thereupon redeemed the retained shares, unless the shares given to the son were redeemed in the same transaction. It is not clear why $\$ 302$ (c) (2)(B) provides that the very shares which were acquired by the related person from the distributee must be redeemed in the same transaction; the purpose of the provision would be served if an equivalent number of other shares were redeemed. Moreover, the provision apparently (and unaccountably) would not be satisfied by a redemption of all the stock of the related person in the same transaction if he had previously transferred to a third party the shares which he acquired from the distributee.

79. T.D. 6152, 26 C.F.R. $\$ 1.302-4(\mathrm{~g})$ (2) (1955). See Senate Report 237.

80. Zenz v. Quinlivan, 213 F.2d 914 (6th Cir. 1954), reversing 106 F. Supp. 57 (N.D. Ohio 1952). See also Auto Finance Co., 24 T.C. 416 (1955), affd, 229 F.2d 318 (4th Cir. 1956), where the ex-shareholder, a corporation, urged that the transaction constituted a "dividend" in order to take advantage of the dividends received credit of the 1939 Code. Int. Rev. Code of 1939, \$26(b), 53 STAт. 18.

81. Rev. Rul. 54-458, 1954-2 Cum. Bul. 167. In acquiescing in Zenz v. Quinlivan, supra note 80 , the Internal Revenue Service stated that "every case in which a stockholder sells part of his stock to new or existing stockholders and thereafter transfers the remainder to the corporation for redemption will be closely scrutinized to determine whether the selling stockholder 'ceases to be interested in the affairs of the corporation' immediately 
It has also announced that such a transaction meets the requirements of section $302(\mathrm{~b})(3)$ of the 1954 Code. $^{82}$ It should not be assumed, however, that section 302(b) (3) will be satisfied by a sale of stock followed by a prearranged redemption of the transferred stock. Such a transaction might be treated as a redemption of part of the shares of the original shareholder, rather than as a redemption of all of the shares of the transferee. ${ }^{83}$

To continue with the illustration of a sale of part of the stock of a one-man corporation followed by a prearranged redemption of the remaining shares, is it possible that the redemption will be treated as a dividend to the purchaser of the other shares? If he bought all the shares and then caused some of them to be redeemed, the redemption would of course not qualify under section $302(b)$ (3) as a redemption of all of his shares. ${ }^{84}$ Under the 1939 Code, moreover, a taxpayer who contracted to buy the stock on the installment plan and then caused the corporation to take over part of his obligation to the seller by redeeming some of the shares was held in Wall v. United States ${ }^{85}$ to have received a dividend. A redemption under such circumstances was considered by the court to be the equivalent of a payment by the corporation of the taxpayer's personal debt:

after the redemption." Id. at 168. The "ceases to be interested" requirement comes from the "old" regulations (see note 13 supra), and may have been intended to exclude an arrangement for paying for the redeemed shares only out of, or in an amount measured by, corporate profits. There is no such ban in the language of $\$ 302(\mathrm{~b})(3)$, and $\S 302(\mathrm{c})(2)$ (A) (i) may support, by negative inference, the conclusion that a redemption of all the stockholder's shares qualifies under $\$ 302(\mathrm{~b})$ (3) even if he possesses an "interest" in the corporation after the redemption. See First, Use of Corporate Funds to Buy Out Shareholders-Acquisitions by Third Parties, N.Y.U. 12TH INST. ON FED. TAx. 191 (1954); Redlich, The Sale of a Closely-Held Corporate Business, 9 TAx L. Rev. 354 (1954); Note, Income Tax Problems in the Use of Stock Redemptions to Purchase a Corporation Out of Future Earnings, 67 HaRv. L. Rev. 1387 (1954) (all written before the district court opinion in Zenz v. Quinlivan, supra note 80 , was reversed by the court of appeals).

82. Rev. Rul. 55-745, 1955-2 Cum. Burl. 223. This ruling states that Rev. Rul. 54-458, 1954-2 Cum. Bull. 167 (see note 81 supra), is "equally applicable under the 1954 Code." It is possible that if a selling shareholder retains an "interest" in the corporation, the Service might assert that the transaction does not come within the terms of its ruling and then proceed to advance the broad contention that a redemption after a sale is no different from a redemption before a sale. The latter transaction could not claim the protection of $\$ 302$ (b) (3), unless the fact that at the time of the redemption the shareholder had already contracted to sell the rest of his shares gives rise, by analogy to the principle of "equitable conversion," to the assumption that he no longer owns them. One writer suggests that a redemption of some shares before a sale of the rest is not essentially equivalent to a dividend. Redlich, The Sale of a Closely-Held Corporate Business, 9 TAX L. REV. 354, 363 (1954).

83. The theory would be that the original shareholder made an anticipatory assignment of a dividend, i.e., the proceeds of redemption. See Rhodes' Estate v. Commissioner, 131 F.2d 50 (6th Cir. 1942).

84. Rev. Rul. 56-265, 1956 INT. Rev. BuLz. No. 25, at 14. See Lowenthal v. Commissioner, 169 F.2d 694 (7th Cir. 1948).

85. 164 F.2d 462 (4th Cir. 1947). 
The controlling fact in this situation was that Wall [the buyer] was under an obligation to pay Coleman [the seller] $\$ 5,000$ in the tax year and that Rosedale [the corporation] paid this indebtedness for Wall out of its surplus. It cannot be questioned that the payment of a taxpayer's indebtedness by a third party pursuant to an agreement between them is income to the taxpayer. . . . The transaction is regarded as the same as if the money had been paid to the taxpayer and transmitted by him to the creditor; and so if a corporation, instead of paying a dividend to a stockholder, pays a debt for him out of its surplus, it is the same for tax purposes as if the corporation pays a dividend to a stockholder, and the stockholder then utilizes it to pay his debt. ${ }^{86}$

The principle of the $W$ all case is not applicable, however, if the buyer agrees to purchase part of the seller's stock, and the corporation agrees simultaneously to redeem the rest. ${ }^{87}$ The Tax Court held in the case of Ray Edenfield ${ }^{88}$ that the redemption did not constitute a dividend to the buyer in a case of this type even though

86. Id. at 464. The theory that the corporation has distributed a disguised dividend by paying the shareholder's debt could not be applied if the corporation received adequate consideration for its payment, e.g., if it took over a shareholder's obligation to buy a commodity and received delivery of the commodity itself. But the corporation derives no benefit from taking over the shareholder's obligation to buy its own shares, even if the shares are delivered to it. The court in the Wall case might have rested its decision solely on the theory that the corporation had paid a disguised dividend by paying the shareholder's debt, a theory that could stand independently of $\S 115(\mathrm{~g})$ of the 1939 Code. The disguised dividend theory could have been applied even by a court adhering to the view that $\$ 115(\mathrm{~g})$ was inapplicable to redeemed shares held as treasury stock. See cases cited in note 53 supra. But while the opinion in the $W$ all case rests in part on the broad theory that the distribution was a payment of the shareholder's debt (which is equally valid under the 1954 Code), it also relies on $\$ 115(\mathrm{~g})$. This statutory foundation for the decision, it might be argued, has been weakened by the 1954 Code. For $\$ 115(\mathrm{~g})$ provided that a redemption "at such time and in such manner" as to be essentially equivalent to a taxable dividend shall be treated as one. This language can be read, without distortion, to mean that if $A$ 's shares are redeemed at a time when $B$ is obligated to buy them, the redemption is equivalent to, and shall be taxed as, a dividend to $B$. But the language of $\$ 115(\mathrm{~g})$ is partly abandoned by $\$ 302$, and $B$ can now argue that $\$ 302(\mathrm{~b})(3)$ flatly provides that a redemption of all of $A$ 's shares is to be treated as a sale of the stock so that there is no occasion to apply $\$ 302$ (d). The Commissioner would be driven to answer that at the time of the redemption the shares were already B's "in substance," so that their redemption does not qualify under $\$ 302(b)(3)$, an argument that might be less congenial to some courts than reliance on the language of old $\$ 115(\mathrm{~g})$.

The Wall case was followed in Woodworth v. Commissioner, 218 F.2d 719 (6th Cir. 1955); Frank P. Holloway, $10 \mathrm{CCH}$ Tax Ct. Mem. 1257 (1951), affd per curiam, 203 F.2d 566 (6th Cir. 1953). See also Thomas J. French, 26 T.C. No. 32 (May 15, 1956).

87. See Fox v. Harrison, 145 F.2d 521 (7th Cir. 1944), where the corporation redecmed part of the stock of a shareholder who owned or controlled about two-thirds of the stock. The balance of his stock was acquired in 1938 by the plaintiff (who owned or controlled about one-third of the stock) with the purpose of causing it to be redeemed as soon as the corporation was financially able to do so. It was held that a later redemption in 1939 of part of the stock so acquired by the plaintiff was not equivalent to a dividend to him, on the ground that the stock was "in reality" acquired by the corporation from the original owner. See Mendle Silverman, $13 \mathrm{CCH}$ Tax Ct. Mem. 527 (1954), where a shareholder tried unsuccessfully to persuade the court that he (like the plaintiff in Fox v. Harrison, supra) had acquired stock as agent for the corporation in anticipation of a redemption.

88. 19 T.C. 13 (1952). 
he pledged his shares to insure that the corporation would perform its part of the bargain, so long as he had no personal obligation to acquire the shares that were redeemed. ${ }^{82}$ The Internal Revenue Service has acquiesced in this decision. ${ }^{90}$ It has been suggested that the $W$ all case would not apply to the intermediate case of a corporate agreement to redeem, performance of which is personally guaranteed by the purchaser of the other shares, but this issue cannot be regarded as entirely settled. ${ }^{91}$ Another problem under the $W$ all case is the extent to which an agreement between buyer and seller, covering all the shares, can be rescinded so as to substitute a corporate obligation to redeem some of the shares for an individual promise to purchase them. An attempt to call off an agreement in order to substitute a corporate obligation, so as to bring a redemption within the Edenfield case rather than the $W$ all case, may be frustrated by the Commissioner with the aid of the Court Holding $\mathrm{Co}^{92}$ doctrine. ${ }^{93}$

\section{Substantially Disproportionate Redemptions: Section 302(b)(2)}

Because an ordinary dividend effects a distribution of property to the corporation's shareholders without disturbing their relative voting power and interest in the assets and earning power of the corporation, a redemption of stock was most likely to qualify as "essentially equivalent to the distribution of a taxable dividend" under section Ir 5 (g) of the I939 Code if it was pro rata among all the shareholders. Conversely, a non-pro rata redemption ordinarily escaped the clutches of section $\operatorname{II}_{5}(\mathrm{~g}){ }^{94}$ Section $302(\mathrm{~b})(2)$ of the I954 Code has carried forward this distinction by providing that a substantially disproportionate redemption is to be treated as a sale

89. Where cash is to be paid for the shares, there would obviously be no practical difference to the buyer between a purchase of all the shares, followed by a redemption from him of some, and a purchase of some shares with a simultaneous redemption of the others from the seller. Under the Edenfield case, however, the difference in form would determine whether the buyer received a dividend or not. If some shares are to be paid for at a later date, the $W$ all case finds a dividend when the individual purchaser agrees to buy and then causes the corporation to take over his obligation, while the Edenfield case protects the purchaser if only the corporation is liable to the seller. Unless the corporation is in a speculative line of endeavor, or the time for payment is long postponed, however, it will rarely matter to either the seller or the individual purchaser (except for tax purposes) whether the latter's credit or only the corporation's is pledged.

90. 1953-1 Cum. BuLl. 4.

91. See Redlich, The Sale of a Closely-Held Corporate Business, 9 Tax. L. REv. 354, 358 (1954).

92. Commissioner v. Court Holding Co., 324 U.S. 331 (1945).

93. See note 168 infra.

94. See note 13 supra. 
or exchange of the stock rather than as a dividend. A shareholder cannot avail himself of section 302(b) (2), however, unless immediately after the redemption he owns, directly and constructively, less than fifty percent of the total combined voting power of all classes of stock entitled to vote. ${ }^{95}$ This restriction on section $302(\mathrm{~b})$ (2) is presumably based on the theory that a reduction in the proportionate ownership of a shareholder is not significant if he remains in control of the corporation after the redemption, as evidenced by the fifty percent of the combined voting power limitation.

To be substantially disproportionate, the redemption must satisfy a mathematical test expressed in section $302(b)(2)(C)$ : the shareholder's percentage of the total outstanding voting stock $^{96}$ (owned directly and constructively) immediately after the redemption must be less than eighty percent of his percentage of such stock immediately before the redemption. The Regulations set out the following example to illustrate section $302(\mathrm{~b})(2)$ :

Corporation $M$ has outstanding 400 shares of common stock of which $A, B, C$ and $D$ each own roo shares or 25 percent. No stock is considered constructively owned by $A, B, C$ or $D$ under section $3^{I} 8$. Corporation $M$ redeems 55 shares from $A, 25$ shares from $B$, and 20 shares from $C$. For the redemption to be disproportionate as to any shareholder, such shareholder must own after the redemptions less than 20 percent ( 80 percent of 25 percent) of the 300 shares of stock then outstanding. After the redemptions, A owns 45 shares ( 15 percent), B owns 75 shares (25 percent), and $C$ owns 80 shares ( $262 / 3$ percent). The distribution is disproportionate only with respect to $A .{ }^{97}$

If the corporation has more than one class of stock outstanding, the shareholder cannot make use of section 302 (b) (2) unless the redemption reduces his percentage of common stock, whether vot-

95. Section 302(c)(1) makes the constructive ownership rules of $\$ 318$ (a) applicable in determining the ownership of stock under $\$ 302(\mathrm{~b})(2)$. See note 96 infra.

96. The term "voting stock" is defined by the Regulations so as to exclude, at least "generally," stock with contingent voting rights. T.D. 6152, 26 C.F.R. $\$ 1.302-3$ (a) (1955). The Regulations do not state whether the term "stock cntitled to vote" (see note 95 supra) is the same as "voting stock." For problems in identifying "voting stock" and "stock entitled to vote" and in computing "voting power," see Bittker, Stock Dividends, Distributions in Kind, Redemptions, and Liquidations Under the 1954 Code, 1955 So. CaIIf. TAX INST. 349, 374-75.

97. T.D. 6152, 26 C.F.R. $\$ 1.302-3(b)$ (1955). The Senate Report twice misapplies the formula by disregarding the fact that the redemption reduces the number of shares outstanding. Senate Report 234-35, 253. See Bernbach, Substantially Disproportionate Redemptions Under the 1954 Act, 33 Taxes 597 (1955); Bittker, Stock Dividends, Distributions in Kind, Redemptions, and Liquidations Under the 1954 Code, 1955 So. Calif. TAX INST. 349, 376-77. 
ing or nonvoting, as well as his percentage of voting stock. ${ }^{98}$ If the corporation redeems only nonvoting stock, whether common or preferred, the redemption cannot qualify under section 302(b) (2) because it will not reduce the shareholder's proportionate ownership of voting stock..$^{99}$ But the redemption of nonvoting stock can qualify, according to the Regulations, if it is coupled with a redemption of voting stock that would qualify if it stood alone. ${ }^{100}$

To prevent an obvious abuse of section 302 (b) (2), the statute explicitly provides that it does not apply to any redemption pursuant to a plan for a series of redemptions which in the aggregate will not be substantially disproportionate with respect to the shareholder. Thus, to return to the illustration above, if the redemption of the stock of $A, B$ and $C$ was in accordance with a plan by which seventy-five of $D$ 's shares would later be redeemed, the redemption of $A$ 's shares would not meet the test of section 302 (b) (2). For after the second step, $A$ would own twenty percent of the total outstanding shares (45 out of 225), an insufficient reduction in his percentage. ${ }^{101}$ The redemption of $D$ 's shares, however, would apparently qualify even though it was the occasion for disallowing the redemption of $A$ 's shares. It should not be assumed that this explicit reference to a plan for a "series of redemptions" is the Commissioner's only weapon against attempts to abuse section 302 (b) (2). If a redemption viewed in isolation is substantially dispropor-

98. The Regulations do not state explicitly whether or not $\S 302(\mathrm{~b})(2)$ can be invoked if the corporation redeems voting preferred stock without simultaneously redeeming common. Since a redemption cannot qualify as substantially disproportionate unless it satisfies the first sentence of $\$ 302(b)(2)(C)$ (requiring a reduction in the shareholder's ownership of voting stock), it seems equally necessary that it satisfy the second sentence of $\$ 302$ (b) (2) (C) (requiring a reduction in his ownership of common stock). The Regulations state flatly that a redemption of nonvoting common stock alone does not qualify as substantially disproportionate, presumably because it could not satisfy the first sentence; and by a parity of reasoning a redemption of voting preferred stock alone would not qualify because it could not satisfy the second sentence. T.D. 6152, 26 C.F.R. 1.302-3(a) (1955).

99. Ibid.

100. Ibid. If a redemption of voting common is accompanied by a redemption of nonvoting preferred, the shareholder's proportion of voting stock and common stock is totally unaffected by the redemption of the nonvoting preferred. The Regulations are on doubtful ground in expressing the view that the latter redemption can ride in on the coattails of the redemption of common. See Bittker, Stock Dividends, Distributions in Kind, Redemptions, and Liquidations Under the 1954 Code, 1955 So. CalIF. TAx Inst. 349, 370 n.67. But see Cohen, Redemptions of Stock Under the Internal Revenue Code of 1954, 103 U. PA. L. Rev. 739, 749-50 (1955).

101. A's percentage after the redemption would be exactly 80 percent $(20 / 25)$ of his percentage before the redemption. But $\S 302(\mathrm{~b})(2)$ fixes the benchmark at "less than 80 percent."

Under the 1939 Code, and without specific statutory direction, an ostensibly nonpro rata redemption was held to be pro rata because of a plan for later redemptions. Boyle v. Commissioner, 187 F.2d 557 (3d Cir.), cert. denied, 342 U.S. 817 (1951). 
tionate as to a shareholder, but the other shareholders have agreed to sell enough stock to him after the redemption to restore the status quo, the redemption will probably not satisfy section 302 (b) (2).

\section{Redemptions Not Essentially Equivalent to Dividends: Section $302(b)(I)$}

Section $302(\mathrm{~b})(\mathrm{I})$ provides that a redemption may be treated like a sale of the redeemed stock if it "is not essentially equivalent to a dividend." The language comes from section II5 (g) of the I939 Code. ${ }^{102}$ The Regulations state that whether section 302 (b) (I) applies "depends upon the facts and circumstances of each case."103 Some commentators have argued that any redemption that could have escaped section II5(g) of the I939 Code will qualify as not essentially equivalent to a dividend under section 302(b) (I).$^{104}$ But the Senate Report rather clearly implies that section 302 is concerned solely with "those distributions which may have capital-gain characteristics because they are not made pro rata among the various shareholders . . . ."105 This general limitation of section 302 (b) to non-pro rata redemptions helps to explain the

102. See pp. 14-15 supra.

103. T.D. 6152, 26 C.F.R. $\$ 1.302-2$ (b) (1955). The Regulations take the surprising position that a distribution may be "essentially equivalent to a dividend," even though the corporation has no earnings and profits, giving as an example the redemption of part of its stock by a one-man corporation without earnings and profits. T.D. 6152, 26 C.F.R. $\$ 1.302-2$ (a) (1955). The consequences of the Regulations can be illustrated by this example: $A$, an individual, purchased all of the stock of Corporation $X$ for $\$ 100,000$. The corporation, at a time when it has no earnings and profits, redeems half of the stock for $\$ 110,000$. Under the Regulations, the distribution falls under $\$ 301$; it would reduce the basis of $A$ 's retained stock to zero, and the excess of $\$ 10,000$ would be taxed as capital gain. If, contrary to the Regulations, the distribution qualified under $\$ 302$ (b)(1) as not essentially equivalent to a dividend because of the absence of earnings and profits, $A$ would have a capital gain of $\$ 60,000$ under $\$ 302$ (a) (proceeds of $\$ 110,000$ less basis of one-half the stack), and the basis of his retained shares would remain intact. The latter result might be preferable if $A$ had an otherwise useless capital loss in the year of redemption against which the capital gain could be offset.

The view of the Regulations that a distribution can be essentially equivalent to a dividend even though the corporation has no earnings and profits is based on the theory that the quoted phrase means "having the same effect as a distribution without any redemption of stock" and is derived from a statement in the SENATE REPORT 234. Presumably the draftsmen of the Senate Report meant either to override the definition of dividend in $\$ 316$ (a) or to adopt the theory that earnings and profits are not an essential characteristic of a dividend.

104. Cohen, Redemptions of Stock Under the Internal Revenue Code of 1954, 103 U. PA. L. Rev. 739, 743-44 (1955); Laikin, Stock Redemptions: Sections 302 and 318, N.Y.U. 14TH INST. ON FED. TAX., 671, 685-86 (1956).

105. Senate Report 49, quoted at p. 17 supra. The statement cannot be applied literally, since $\$ 302$ (b) (4) (redemption of certain railroad stock) is applicable to a pro rata redemption, but it is reasonable to assume that, with this minor exception, the statement in the Senate Report is an authoritative explanation of $\$ 302$. 
meaning of this statement regarding section $302(b)(x)$ in the Senate Report:

Subsection (b) of section 302 states three conditions in paragraphs (I), (2), (3), and (4), the satisfaction of any one of which will result in the treatment of the redemption as a distribution in full or part payment in exchange for the stock. In general, under this subsection your committee intends to incorporate into the bill existing law as to whether or not a redemption is essentially equivalent to a dividend under section II $(\mathrm{g})(\mathrm{r})$ of the 1939 Code, and in addition to provide three definite standards in order to provide certainty in specific instances.

Paragraph (I) of subsection (b) provides that subsection (a) will apply if the redemption is not essentially equivalent to a dividend.

The test intended to be incorporated in the interpretation of paragraph (I) is in general that currently employed under section $\operatorname{Ir} 5(\mathrm{~g})(\mathrm{I})$ of the I939 Code. Your committee further intends that in applying this test for the future that the inquiry will be devoted solely to the question of whether or not the transaction by its nature may properly be characterized as a sale of stock by the redeeming shareholder to the corporation. ${ }^{108}$

Still further evidence in support of a very restricted application of section $302(\mathrm{~b})(\mathrm{I})$ is its history. It was added by the Senate Finance Committee after the passage by the House of Resolution $8300,{ }^{107}$ providing for capital gains treatment primarily in circumstances similar to those now set out in section $302(\mathrm{~b})(2)$ (substantially disproportionate redemptions) and section $302(\mathrm{~b})(3)$ (terminations of the shareholder's entire stock interest).$^{108}$ The Senate Finance Committee explained the addition of the general language of section 302(b) (I) in the Senate Report as follows:

While the House bill set forth definite conditions under which stock may be redeemed at capital-gain rates, these rules appeared unnecessarily restrictive, particularly, in the case of redemptions of preferred stock which might be called by the corporation without the shareholder having any control over when the redemption may take place. Accordingly, your committee follows existing law by reinserting the general language indicating that a redemption shall be treated as a distribution in part or full payment in exchange for stock if the redemption is not essentially equivalent to a dividend. ${ }^{109}$

It is not easy to give section $302(\mathrm{~b})(\mathrm{I})$ an expansive construction in view of this indication that its major function was the narrow

106. Senate Report 233-34.

107. H.R. 8300, $83 \mathrm{~d}$ Cong., $2 \mathrm{~d}$ Sess. (1954).

108. Id. $\$ 302(\mathrm{a})$.

109. SENATE REPORT 44-45. 
one of immunizing redemptions of minority holdings of preferred stock.

Against this background, it is not surprising that the only example of a section 302 (b) (I) redemption to be found in the Regulations is a redemption of one-half of the nonvoting preferred stock of a shareholder who owns no shares of any other class. ${ }^{110}$ The redemption could not qualify under section $302(\mathrm{~b})$ (2) since no reduction in voting stock results from the redemption ${ }^{111}$ or under section 302 (b) (3) since not all of the shareholder's stock is redeemed. ${ }^{122}$ The redemption may be pro rata among all the owners of nonvoting preferred stock, but it is not pro rata in the broader sense unless they also own common stock in the same proportion; and the transaction "may properly be characterized as a sale of stock by the redeeming shareholder to the corporation." The sale analogy was also applied in a recent ruling to the redemption of stock from a group of four trusts which, with their beneficiaries and the families of the beneficiaries, owned eleven percent of the stock of the corporation. Another five percent of the stock was owned by trusts created for cousins of the trust beneficiaries, and the remaining eighty-four percent was owned by strangers. The redemption apparently did not qualify as substantially disproportionate under section $302(\mathrm{~b})(2)$, but because of the minority position of the trusts whose shares were redeemed, the transaction could properly be characterized as a sale of the stock. ${ }^{114}$ To be sure, a redemption that is disproportionate but not substantially so should not be allowed to use section 302 (b) (I) as an easy escape from the rigor of section 302 (b) (2). But the redemption of a few shares from a minority shareholder can properly be called a nonpro rata redemption, even though it is not substantially disproportionate within the meaning of section $302(\mathrm{~b})(2)$. In another

110. T.D. 6152,26 C.F.R. $\$ 1.302-2$ (a) (1955). As to constructive ownership, see note 117 infra.

111. See T.D. 6152,26 C.F.R. $\$ 1.302-3$ (a) (1955).

112. T.D. 6152, 26 C.F.R. \$1.302-2(a) (1955). See INT. REv. CODE of 1954, \$302(b) (5).

113. SENATE Report 233-34. The Regulations state that the redemption will "ordinarily" qualify. T.D. 6152,26 C.F.R. $\$ 1.302-2$ (a) (1955). The reservation may be intended to exclude transactions that are more appropriately treated as dividends than as sales, e.g., a redemption of preferred stock transferred by gift by a controlling shareholder in anticipation of a redemption. See William S. Grimditch, 37 B.T.A. 402, 412 (1938).

114. Rev. Rul. 56-183, 1956 INT. Rev. BurL. No. 18, at 29. While the ruling does not so state, it is reasonable to assume that the four trusts did not in fact control the corporation. The absence of a market for the shares suggests that the 84 percent held by strangers was not so widely scattered as to leave working control of the corporation in the four trusts. 
recent ruling in which a redemption was held to qualify under section $302(\mathrm{~b})(\mathrm{x})$, although it was not substantially disproportionate under section $302(b)(2)$, the Internal Revenue Service noted that:

In the instant case, the transaction . . . by its nature can be characterized as a sale of stock by the shareholder. The two shareholders are unrelated and there is no pro rata distribution in whole or part effected by the transaction. ${ }^{115}$

The Regulations under section 302(b)(r) state that if a corporation has only one class of stock outstanding, a pro rata redemption "generally" will be treated as a distribution under section zor, and that if a corporation has more than one class outstanding, a redemption of an entire class will also generally come under section $30 r$ if all classes of stock are held in the same proportion. ${ }^{116}$ No doubt many fervent arguments will be based on that phrase "generally" in an effort to bring some pro rata redemptions under the protection of section $302(\mathrm{~b})(\mathrm{I})$. One instance in which the argument may succeed is the redemption that is pro rata only because of the constructive ownership rules of section 318(a), which the Regulations state is one of the facts to be considered in determining whether a distribution is not essentially equivalent to a dividend. ${ }^{127}$ This statement, which is weaker than the position that had been taken in the proposed Regulations, ${ }^{118}$ may open the door to proof that by reason of family estrangement, for example, shares owned by a spouse or by children should not be attributed to the taxpayer whose shares are being redeemed, thus allowing the redemption to qualify under section $302(\mathrm{~b})(\mathrm{I})$ although the attribution rules would prevent qualification under section $302(b)(2)$. More dubious is the possibility of applying section $302(\mathrm{~b})(\mathrm{I})$ to a redemption that is undeniably pro rata but which serves a corporate purpose that might have led to nondividend treatment under the 1939

115. Rev. Rul. 55-462, 1955-2 Cum. Bull. 221. See also Rev. Rul. 56-485, 1956 INT. Rev. Bull. No. 40 , at 10 .

116. T.D. 6125, 26 C.F.R. $\$ 1.302-2$ (b) (1955).

117. Ibid. Section 318(a) states that its rules are to be applied only where "expressly made applicable." Section 302(c)(1) states that these rules shall "apply in determining the ownership of stock for purposes of this section." It has been argued that they are not applicable under $\$ 302$ (b) (1) because it does not expressly refer to the "ownership" of stock. Cohen, Redemptions of Stock Under the Internal Revenue Code of 1954, 103 U. PA. I. REv. 739, 758-59 (1955). But the rules of $\$ 318$ (a) are "expressly" made applicable "in determining the ownership of stock" under $\$ 302$, and consequently it is reasonable to apply them whenever ownership of stock is relevant, whether by statutory direction or otherwise.

118. Proposed Regulations, $\$ 1.302-2$ (b), 19 FED. REg, 8239 (1954). 
Code. Examples are the acquisition by the corporation of shares for resale to junior employees or the improvement of the corporate balance sheet by a redemption in cancellation of debts owed by the shareholders to the corporation. ${ }^{119}$ The repeated references in the Senate Report to non-pro rata distributions and the guarded phraseology of the Regulations are hardly conducive to the wholesale importation into section 302(b) (I) of pre-r954 law. Moreover, the rulings of the Internal Revenue Service manifest, so far at least, an intent to confine section 302(b) (I) to non-pro rata redemptions. ${ }^{120}$ To those already mentioned may be added a recent ruling which held that a redemption of some of the stock of a majority shareholder to enable an employee to increase his holdings under an earlier stock option agreement is essentially equivalent to a dividend because it did not produce an "appreciable change in position of the parties involved."121 Another illustration of the same reluctance to convert section 302 (b) (I) into an escape from section 302 (b) (2) is a ruling that redemption of the stock of a decedent's estate, which was not substantially disproportionate under section $302(b)(2)$ because of the constructive ownership rules, is a dividend in its entirety, notwithstanding the corporation's obligation to redeem part of the stock upon the decedent's death under an earlier agreement. ${ }^{122}$

\section{Redemption by Affiliated Corporation}

Section 302, which determines when stock redemptions shall be treated as exchanges of the stock and when as dividend distributions, applies to a redemption by a corporation of "its" stock. What if a corporation purchases the stock of another corporation? If the two corporations are not affliated in any way, there is no reason why the transaction should not be taken at face value and treated as an ordinary purchase of stock by the corporation so that the seller will realize capital gain or loss. But should the same rule apply if the two corporations are affiliated, e.g., if a shareholder

119. See Bittker, Stock Dividends, Distributions in Kind, Redemptions and Liquidations Under the 1954 Code, 1955 So. CalIF. Tax INST. 393-94.

120. See Rev. Rul. 56-485, 1956 INT. Rev. Bull. No. 40, at 10; Rev. Rul. 56-183, 1956 INT. Rev. Burl. No. 18, at 29; Rev. Rul. 55-462, 1955-2 Cum. Bull. 221.

121. Rev. Rul. 56-182, 1956 INT. Rev. Bull. No. 18, at 28, 29. See also Rev. Rul. 55-515, 1955-2 Cuns. Burl. 222. But note that it has been held that a redemption of stock for the purpose of resale is not pro rata, over the long run, because the resale disturbs the relative position of the shareholders. Smith v. United States, $131 \mathrm{Ct}$. Cl. 748, $130 \mathrm{~F}$. Supp. 586 (1955).

122. Rev. Rul. 56-103, 1956 INT. Rev. BuLl. No. 12, at 7. 
sells stock in a parent corporation to a subsidiary? The net effect of such a transaction is about the same as a distribution of assets by the subsidiary to its parent, followed by a redemption by the parent of its own stock. Had the transaction taken the latter form, it would have been taxed as a section 3 or distribution unless it qualified under section $302(b)(x)$ (not essentially equivalent to a dividend), section $302(b)(2)$ (substantially disproportionate redemptions), section 302(b) (3) (termination redemptions) or section 303 (redemptions to pay death taxes). But when the Commissioner sought, under section II5(g) of the I939 Code, to tax the shareholder of a parent corporation who had sold stock in the parent to its subsidiary, the transaction was held not to be a redemption by the subsidiary of "its" stock. ${ }^{123}$ The 1939 Code was thereupon amended by the Revenue Act of $195^{124}$ to require such a transaction to be treated as though the subsidiary had distributed assets to its parent and the parent had redeemed its own stock.

The 1950 legislation did not purport to reach an alternate method of achieving a similar result. If $A$ owns all the stock of two corporations, and sells the stock of one to the other, the economic consequences are the same as though the second corporation had distributed property to him without any surrender of stock, except for the fact (which would often lack any practical consequences) that the second corporation now owns some of the stock of the first corporation. Nevertheless, the Internal Revenue Service was unsuccessful in its efforts to tax such a "brother-sister" redemption as a dividend. ${ }^{125}$

The 1954 Code, however, not only carried forward the $195^{\circ}$ legislation on parent-subsidiary redemptions, but also enacted new rules to govern brother-sister redemptions. ${ }^{126}$ Under section 304, if a subsidiary corporation acquires the stock of a parent, the transaction is to be treated as a redemption by the corporation that

123. Rodman Wanamaker Trust, 11 T.C. 365 (1948), aff'd per ctriam, 178 F.2d 10 (3d Cir. 1949).

124. Int. Rev. Code of 1939, $\$ 115(\mathrm{~g})(2)$, added by 64 Stat. 932 (1950).

125. Roger W. Pope, 15 CCH Tax Ct. Mem. 181 (1956); Emma Cramer, 20 T.C. 679 (1953). The Internal Revenue Service has ruled that when a sole shareholder of two corporations "sells" stock in one to the other, "there is no economic reality to the sale insofar as any relinquishment of interest by the sole shareholder . . . is concerned," and that the proceeds of the "sale" constitute an ordinary dividend to the extent of the earnings and profits of the acquiring corporation. Rev. Rul. 55-15, 1955-1 Cum. Burl. 361. Although the ruling was directed to the facts of a particular transaction, it was probably intended to have general application.

126. INT. Rev. Code of 1954, \$304. An attempt by the House of Representatives to include a similar provision in the 1950 legislation (see note 124 supra) was repulsed by the Senate. S. Rep. No. 2375, 81st Cong., 2d Sess. 42 (1950). 
issued the stock. But if a brother corporation acquires the stock of a sister corporation, the transaction is to be treated as a redemption by the corporation that acquired the stock. In neither instance, however, is the redemption necessarily a section 301 distribution. It may be treated as an exchange if it can meet the test of sections $302(b)$ or 303 .

It has been suggested that every brother-sister pair of corporations is also, by reason of the constructive ownership rules of sections 304 and 318 , a parent-subsidiary group. ${ }^{127}$ This suggestion is based on the fact that if a person is in control of two corporations, his stock in each one is attributed to the other, so each corporation is in control of the other. The Regulations assume to the contrary that brother-sister corporations can be distinguished from parentsubsidiary corporations. ${ }^{128}$ This assumption must have been shared by the draftsmen of the I954 Code and finds support in the statement in section $304(\mathrm{~b})(2)(B)$ that the acquisition by a subsidiary of its parent's stock shall be taxed "as if the property were distributed by the acquiring corporation to the issuing corporation and immediately thereafter distributed by the issuing corporation." Since the hypothetical distribution by the acquiring corporation to

127. Owen, Stock Redemptions and Partial Liquidations Under the 1954 Code, 32 TAXEs 979,988 (1954).

128. T.D. 6152,26 C.F.R. $\$ 1.304-2$ (1955). The Regulations give three examples of brother-sister redemptions. T.D. 6152, 26 C.F.R. \$1.304-2(c) (1955). In each example, however, Corporation $X$ could be regarded as the parent of Corporation $Y$ before the sale on the theory that it constructively owns 50 percent or more of the stock of Corporation $Y$ because $X$ 's shareholders do.

Apparently $\$ 304$ looks only to control immediately before the sale of stock. But even if control must exist after the sale, in each of the examples in the Regulations Corporation $X$ is the parent of Corporation $Y$ after, as well as before, the sale. In example (1), after the sale Corporation $X$ constructively owns the 50 shares of Corporation $Y$ owned by $X$ 's shareholder $B$. Moreover, Corporation $X$ also constructively owns the 50 shares of Corporation $Y$ owned by $X$ 's shareholder $A$. While $\$ 318(\mathrm{a})(2)(\mathrm{C})$ attributes a shareholder's stock to his corporation ("back attribution") only if he owns 50 percent or more of the latter's stock, $\$ 304(\mathrm{c})(2)$ removes the 50 percent limitation of $\$ 318(\mathrm{c})(2)(\mathrm{C})$, with the result that a corporation is charged with all the stock owned by minority shareholders. In example (2), after the sale Corporation $X$ constructively owns the 50 shares of Corporation $Y$ owned by $X$ 's shareholder $A$. In example (3), after the sale Corporation $X$ constructively owns the 75 shares of Corporation $Y$ owned by $X$ 's shareholders $W, S$ and $G$.

Even if the shareholder disposes of all his stock in the issuing corporation, he continues to be a constructive shareholder in it because a portion of the stock he has just disposed of is attributed to him as a shareholder in the acquiring corporation, and the issuing corporation is therefore charged with his stock in the acquiring corporation. The only way the chain can be broken is by a simultaneous sale of all of the stock owned, directly and constructively, in each corporation to the other. Thus, if in example (2), $A$ sold his 50 shares of Corporation $X$ stock to Corporation $Y$ and simultaneously sold his 50 shares of Corporation $Y$ stock to Corporation $X$, neither corporation would own stock, even constructively, in the other. As indicated above, however, \$304 apparently looks only to control before the sale. If so, the simultaneous sale of stock in each corporation to the other would not prevent the application of $\$ 304(\mathrm{a})(2)$. The transaction would qualify for capital gain or loss treatment, however, under $\$ 302(b)(3)$. 
the issuing corporation could occur only if the latter were in a chain of actual ownership (i.e., an actual parent, grandparent, etc.), it is reasonable to limit the parent-subsidiary rule of section 304 (b) (2) (B) to corporations that could have distributed the property upward in an unbroken chain of actual ownership, relegating the brother-sister rule of section $304(\mathrm{~b})(2)(\mathrm{A})$ to other related corporations. This may be the theory that underlies the examples in the Regulations. ${ }^{129}$

\section{Redemptions to Pay Death TaXes}

Section 303 provides that in certain cases a redemption of stock, the value of which has been included in the gross estate of a decedent for federal estate tax purposes, shall be treated as a sale of the stock. Where the conditions of section 303 are met, the redemption is treated as a sale even though it would, but for section 303 , be taxed as a dividend under section 302(d). For example, if all the stock of a corporation is held by an estate, a redemption of part of the stock would not qualify for capital gains treatment under section 302 (b) (2) (substantially disproportionate redemptions) or under section $302(\mathrm{~b})$ (3) (redemptions in termination of a shareholder's interest), nor in the absence of other relevant facts could it qualify under section 302 (b) (r) (redemptions not essentially equivalent to a dividend) or section $33 \mathrm{I}(\mathrm{a})$ (2) (partial liquidations). If the conditions of section 303 are satisfied, however, such a redemption would be treated as a sale. ${ }^{130}$ Another example is the redemption of stock from an estate when the rest of the shares are owned by the sole beneficiary of the decedent's estate. Because of the constructive ownership rules, the redemption of part or all of the estate's stock could not qualify under sections 302 (b) (2) or 302(b) (3). Yet it could qualify under section 303 for treatment as a sale rather than a dividend.

Section 303 contains the following conditions and limitations:

I) The value of the redeemed stock ${ }^{131}$ must be included in de-

129. T.D. 6152, 26 C.F.R. $\$ 1.304-2$ (c) (1955).

130. Neither gain nor loss would be realized, however, if the redemption price was equal to the fair market value of the shares at the date of death (or on the optional valuation date, in the case of an election under $\$ 2032$ ), by virtue of $\$ 1014(\mathrm{a})$.

131. If stock was included in the gross estate and could have been redeemed under $\S 303$, the same privilege is extended by $\$ 303$ (c) to a redemption of "new" stock having a basis determined by reference to the basis of the stock that was actually included. Section 303 (c) permits the redemption of stock acquired after death as a stock dividend or in a recapitalization or other tax-free cxchange, and may be helpful if a redemption of the original stock would have disturbed the voting rights of the shareholders.

A redemption under $\S 303$ is permissible even though the stock to be redeemed is 
termining the gross estate of a decedent for federal estate tax purposes. ${ }^{132}$ This requirement is satisfied if the value of the stock was included because it was transferred in contemplation of death, because the decedent had a power of appointment over it, because it was held in joint tenancy with the decedent, etc. ${ }^{133}$ The stock need not have been owned by the decedent at the time of his death.

2) The stock of the corporation, whether redeemed or not, must make up more than thirty-five percent of the decedent's gross estate or fifty percent of his taxable estate. ${ }^{134}$ In order to satisfy the thirty-five percent or fifty percent requirement, the stock of two or more corporations may sometimes be aggregated. ${ }^{135}$

3) The total application of section 303 cannot exceed the sum of the death taxes imposed because of the decedent's death ${ }^{136}$ and the funeral and administration expenses allowable as deductions for federal estate tax purposes. ${ }^{137}$

4) The benefits of section 303 are available only to amounts distributed after the death of the decedent ${ }^{138}$ and within a limited period (ordinarily four and one-half years) thereafter. ${ }^{139}$

Section 303 is an expanded version of a provision that was

section 306 stock, according to the Regulations. T.D. 6152, 26 C.F.R. $\$ 1.302-2$ (d) (1955). Although the statute is not specific on this point, the Senate Report takes the same position. SENATE REPORT 239.

132. INT. REv. CODE OF 1954, \$303(a).

133. T.D. 6152,26 C.F.R. $\$ 1.303-2$ (b) (1955)

134. INT. REv. CODE of 1954, \$303(b) (2) (A).

135. Id. $\S 303(\mathrm{~b})(2)(\mathrm{B})$.

136. Id. $\$ 303(\mathrm{a})(1)$.

137. Id. $\$ 303$ (a) (2). The Regulations quite properly restrict the "total application" of $\S 303$ in this manner, as did the old U.S. Treas. Reg. 118, $\$ 39.115(\mathrm{~g})-1(\mathrm{c})(6)(1953)$, although a literal reading of the statutory language would permit each owner of stock included in the estate to receive a distribution equal to the sum of the death taxes and the funeral and administration expenses. T.D. 6152, 26 C.F.R. $\$ 1.303-2(\mathrm{~g})$ (1955).

Suppose the corporation distributes $\$ 15,000$ to $A$ and, at a later date, $\$ 15,000$ to $B$, each distribution qualifying under $\$ 303$ except that the total death taxes and funeral and administration expenses amount in the aggregate to only $\$ 15,000$. The Regulations do not state whether the allowance is granted to $A$ alone or is to be split evenly between $A$ and $B$. The latter approach would have the disadvantage of making it impossible to ascertain the effect of the first distribution until the entire period of time allowed by $\S 303(\mathrm{~b})(1)$ had run. See note 139 infra. The Regulations seem to indicate that, in any event, $B$ can derive no benefit from the fact that $A$ could have claimed exchange treatment for the redemption under another provision of law, such as $\$ 346(\mathrm{a})(2)$ or $\$ 302(\mathrm{~b})(3)$. T.D. 6152,26 C.F.R. $\$ 1.303-2(\mathrm{~g})$ (1955). This seems reasonable, since the purpose of $\$ 303$ is to make funds available to pay estate taxes free of the tax on dividend income. If a redemption under $\$ 346(\mathrm{a})(2)$ or $\$ 302(\mathrm{~b})(2)$ has already accomplished this end, there is no reason for the addition of $\$ 303$ benefits.

138. INT. REv. CODE OF 1954, §303(b) (1).

139. Id. $\$ 303$ (b)(1)(A). The federal estate tax return is due 15 months after death. Id. $\$ 6075$ (a). The tax may be assessed at any time within 3 years after the return was filed. Id. $\$ 6501(\mathrm{a})$. And $\$ 303(\mathrm{~b})(1)(\mathrm{A})$ requires that the distribution be made not later than 90 days after the assessment period. But if a timely petition is filed with the Tax Court for a redetermination of a deficiency in the estate tax, the time is extended by $\S 303(\mathrm{~b})(1)(\mathrm{B})$ until 60 days after the Tax Court decision becomes final. 
enacted in $1950,{ }^{140}$ whose purpose was then stated by the House Committee on Ways and Means as follows:

It has been brought to the attention of your committee that the problem of financing the estate tax is acute in the case of estates consisting largely of shares in a family corporation. The market for such shares is usually very limited, and it is frequently difficult, if not impossible, to dispose of a minority interest. If, therefore, the estate tax cannot be financed through the sale of the other assets in the estate, the executors will be forced to dispose of the family business. In many cases the result will be the absorption of a family enterprise by larger competitors, thus tending to accentuate the degree of concentration of industry in this country.

Your committee is of the opinion that remedial action is desirable in order to prevent the enforced sale of the family businesses which are so vital and desirable an element in our system of free private enterprise. ${ }^{141}$

Despite its stated purpose of protecting against forced sales, the danger of which may have been exaggerated, ${ }^{142}$ section 303 may be employed whether the estate is liquid or not. Even more surprising, stock may be redeemed from specific legatees of stock, donees of gifts in contemplation of death, trustees of inter vivos trusts, etc., even though they may have no obligation to pay any of the death taxes or expenses that give rise to a section 303 redemption. ${ }^{143}$ The statement in the $195^{\circ}$ House Report that "the circumstances under

140. Int. Rev. Code of 1939, $\$ 209$, added by 64 STAT. 932 (1950).

141. H.R. ReP. No. 2319, 81 st Cong., 2d Sess. 63,64 (1950). For pre-1954 law, see Aarons, Redemption of Stock to Pay Death Taxes, 1952 So. Calm. TAx Inst. 253; Dean, The New Section $115(\mathrm{~g})$ Regulations, N.Y.U. 11 TH INST. ON FED. TAx. 587 (1953).

142. See Harriss, Estate Taxes and the Family-Owned Business, 38 Calif. L. Rev. $117,142-44$ (1950).

143. The Regulations state that $\$ 303$ "will most frequently have application in the case where stock is redeemed from the executor or administrator of an estate," and then go on to say that it is also applicable to stock included in the decedent's gross estate and "held at the time of the redemption by any person who acquired the stock by any of the means comprehended by" $\$ \$ 2031-44$ of the Internal Revenue Code (i.e., the provisions defining the gross estate for federal estate tax purposes). The Regulations deny the benefits of $\S 303$ to persons who acquired their stock by gift or purchase from a person "to whom such stock has passed from the decedent," or "from the executor in satisfaction of a specific monetary bequest." T.D. 6152, 26 C.F.R. $\$ 1.303-2$ (f) (1955). In thus excluding the transferees of qualified persons, the Regulations carry out the purpose of $\$ 303$, although it contains no explicit limitation of this type.

Because $\$ 303$ benefits are available to donees in contemplation of death and similar transferees of the decedent, such persons may ally themselves with the Commissioner in an effort to establish that their stock should be included in the gross estate, contrary to the position of the executor. To this incentive is added the stepped-up basis that the stock, whether redeemed or not, will get under $\$ 1014(\mathrm{~b})(9)$ if it is included in the gross estate. The benefits of $\$ 303$ and $\$ 1014($ b $)(9)$ may outweigh the estate tax cost of including the stock in the estate, or the shareholder may not care about the estate tax cost because it will have to be paid by someone else (e.g., the residuary legatees in a case where apportionment of the estate tax is not required). 
which ... relief is available are narrowly defined and will restrict relief to situations in which true hardship exists"144 is not an accurate description either of the r950 legislation or of section 303 as it exists today.

\section{Collateral Problems}

Among the collateral problems that may arise on a partial liquidation or stock redemption are the following.

\section{Computation of Shareholder's Gain or Loss}

Since a distribution in partial liquidation is to be treated under section $33 \mathrm{I}(\mathrm{a})$ (2) as "payment in exchange for the stock," gain or loss is computed as though the stock had been sold. The same is true of a nondividend redemption which under section $302(\mathrm{a})$ is to be "treated as a distribution in part or full payment in exchange for the stock" or of a redemption to pay death taxes under section 303. If the shareholder owns stock purchased at different times and for different prices, he may select the shares to be surrendered to the corporation for redemption, using shares with a high or low basis and a short or long holding period, as he chooses. ${ }^{145}$

But while the shareholder may be able to control the tax consequences of the transaction by shrewdly selecting the shares to be surrendered, he ought not to be able to manipulate the gain or loss to be recognized by surrendering more shares than would be called for in an arm's length transaction. If the redemption is not pro rata, market value will ordinarily govern the number of shares surrendered. But in the case of a pro rata redemption, the number of shares to be surrendered will usually be a matter of indifference to the shareholders. Thus, if Corporation $X$ has a net worth of $\$ 100,000$, represented by one hundred shares of common stock, owned one-half by $A$ and one-half by $B$, and it distributes $\$ 40,000$ in partial liquidation, one would expect $A$ and $B$ to surrender twenty shares each for redemption, but $A$ and $B$ could just as well surrender twenty-five shares each. Can they minimize their capital gain or create capital losses, by doing so? It is said that the practice

144. H.R. REp. No. 2319, 81st Cong., 2d Sess. 53 (1950).

145. John P. Elton, 27 B.T.A. 111 (1942). See Rule v. Commissioner, 127 F.2d 979 (10th Cir. 1942). If the shares cannot be identified by date and price of acquisition, however, the shareholder will have to compute gain or loss on the first-in, first-out basis. U.S. Treas. Reg. 118, §39.22(a)-8 (1953), Courtenay D. Allington, 31 B.T.A. 421 (1934). The Commissioner may select an "average cost" basis. Dictum, id. at 424. If designated shares are called for redemption by the corporation, however, the shareholder may not be free to substitute other shares with a different basis or holding period. 
of the Internal Revenue Service is to ignore the actual number of shares surrendered and tax the transaction as though the ratio of the distribution to the corporation's net worth had governed the number of shares to be redeemed. ${ }^{148}$ Applied to the example above, this practice would require recasting the transaction as though $A$ and $B$ had each surrendered twenty shares. ${ }^{147}$ If this were done, possibly the surrender and redemption of the other five shares per person would be treated as a contribution to capital, increasing the basis of his retained shares. In a number of litigated cases, however, shares were redeemed at par value, original cost, book value or other artificial prices, and the shareholder's gain or loss was apparently computed on this basis, rather than by recasting the transaction as suggested above. ${ }^{148}$ But in some instances, the use of an artificial price in determining the number of shares to be redeemed has been regarded by the courts as an indication that the transaction was "essentially equivalent to the distribution of a taxable dividend" under section II5(g) of the r939 Code. ${ }^{140}$

Another problem arises if the shareholder surrenders too few shares. To vary the foregoing example, what would be the result if $A$ and $B$ surrendered only ten shares each for redemption? One possibility would be to accept the transaction as the parties framed

146. Oberndorfer, Partial Liquidations, N.Y.U. 13TH INST. oN FED. TAX. 637, 650 (1955); Silverstein, Stockholder Gains and Losses on Partial Liquidations, N.Y.U. 14TH INST. ON FED. TAX. 707, 711 (1956). This practice would require a determination of the corporation's net worth, which in turn would require a valuation of good will and other elusive assets.

Just as this Article went to press, the Internal Revenue Service said with reference to a distribution of cash that constituted a partial liquidation under $\$ 331$ (a) (2): "In determining the amount of the gain or loss, regardless of the actual number of shares surrendered for redemption by the stockholders, the total number of shares deemed to have been surrendered is that number which bears the same ratio to the total number of shares outstanding as the cash distributed bears to the total fair market value of the net assets of the corporation immediately prior to the distribution." Rev. Rul. 56-513, INT. REV. BuLL. No. 42 , at $16,18$.

147. If the 25 shares actually surrendered were purchased at different times and different prices, could the Commissioner designate which 20 shares are to be used in the computation of each shareholder's gain or loss? Silverstein, supra note 146 , seems to state that the administrative practice is to use an appropriate fraction of the aggregate basis of all shares, both those redeemed and those retained, in computing the shareholder's gain or loss.

148. Keefe v. Cote, 213 F.2d 651 (1st Cir. 1954) (minority shareholder paid substantially more than majority holder); Commissioner v. Snite, 177 F.2d 819 (7th Cir. 1949) (redemption at "somewhat" below market value); Sam Rosania, Sr., 15 CCH Tax Ct. Mem. 580 (1956) (par and cost); J. Paul McDaniel, 25 T.C. 276 (1955) (varied prices; aggregate proceeds equal to cost); Joseph W. Imler, 11 T.C. 836 (1948) (par value and cost).

149. Pullman, Inc., 8 T.C. 292, 297 (1947). See Lida E. Malone, 45 B.T.A. 305, 310 (1941), rev'd, 128 F.2d 967 (5th Cir. 1942). See also Hellman v. Helvering, 68 F.2d 763 (D. C. Cir. 1934). 
it and compute gain or loss accordingly. Another possibility would be to view the transaction as though $A$ and $B$ had each surrendered twenty shares, with an appropriate reduction in the basis of the retained shares. Still another possibility would be to treat the transaction as though $A$ and $B$ had each received $\$$ ro,00o in exchange for ten shares plus a $\$$ ro,00o dividend. A recent ruling, stating that a certain redemption constituted a partial liquidation "to the extent that the distribution does not exceed the fair market value of the stock being redeemed,"150 suggests by negative inference that if the distribution exceeds the value of the redeemed stock, the excess would be a section 301 distribution.

Still another problem is the deductibility of a loss, if the shareholder receives less than the adjusted basis of the shares redeemed. Section 267 disallows losses on the sale or exchange of property between an individual and a corporation of which he owns more than fifty percent of the stock. ${ }^{151}$ It goes on, however, to make an exception for "losses in cases of distributions in corporate liquidations." This phrase (as used in section $24(b)^{152}$ of the r939 Code) probably immunized all nondividend redemptions, ${ }^{153}$ whether they would be classified by the 1954 Code as partial liquidations under sections $33 \mathrm{I}(\mathrm{a})(2)$ and 346 or as redemptions under section 302(a). A continuation of the pre-r954 meaning of the phrase is suggested by the apparent lack of any intention to narrow its meaning in $1954,{ }^{164}$ but there is at least a possibility that it no longer applies to losses on stock redemptions that do not constitute partial liquidations under section 346 .

Even if the loss is not disallowed by section $26 \%$, however, it is not necessarily deductible. The case of Higgins v. Smith ${ }^{155}$ is still to be conjured with, and it might lead to the disallowance of a loss on the partial liquidation of a one-man corporation, especially if

150. Rev. Rul. 54-408, 1954-2 Cum. Buz. 165, 166. See also Roger W. Pope, 15 CCH Tax Ct. Mem. 181 (1956); T.D. 6152, 26 C.F.R. $\$ 1.301-1(j)$ (1955). But see Rev. Rul. 56-513, INT. Rev. Bull. No. 42, at 16.

151. Section 267 has its own set of constructive ownership rules, different from those found in $\$ 318(\mathrm{a})$.

152. Int. Rev. Code of $1939, \S 24(b), 53$ Stat. 16.

153. Id. $\$ 115$ (i), 53 STAT. 48, defined the term "amounts distributed in partial liquidation" only for purposes of $\S 115$. But there is no reason to think that the term "distributions in liquidation" in id. $\$ 24(\mathrm{~b})(1)(\mathrm{B}), 53$ STAT. 16, did not embrace all partial liquidations, whether resulting from a corporate contraction or a non-pro rata redemption.

154. Senate Report 226. The definition of partial liquidation in $\$ 346$ is for purposes of subchapter C only; hence it is not necessarily controlling under $§ 267$.

155. 308 U.S. 473 (1940). 
the transaction was tax-motivated. ${ }^{156}$ Where there are a number of shareholders, however, Higgins $v$. Smith should not imperil the deduction if control is dispersed or if the shareholders are affected unequally by the redemption.

\section{The Mystery of the Disappearing Basis}

When the redemption of stock is treated as a sale, either because the transaction is a partial liquidation or because it is a nondividend redemption (under sections 302 (a) or 303), the taxpayer can offset the basis of the stock against the proceeds of the redemption. But if the redemption is taxed as a dividend, the mystery of the disappearing basis presents itself. For example, if $A$ purchases all the stock of Corporation $X$ for $\$$ roo,00o and half of the stock is later redeemed for $\$ \mathrm{I}_{50,000}$ in a transaction that constitutes a taxable dividend, does the basis of the redeemed shares disappear? If $A$ had received an ordinary dividend of $\$ 550,000$, without any surrender of shares, his cost basis of $\$ 100,000$ would be intact. There is no reason why he should be in a worse position when the dividend of $\$$ I50,000 is distributed in redemption of some of his stock. It is said that under the I939 Code the Internal Revenue Service made appropriate adjustments to preserve the shareholder's basis,

156. The cases are inconclusive. In Hellman v. Helvering, 68 F.2d 763 (D.C. Cir. 1934), a sole shareholder surrendered 500 shares, with a basis of $\$ 50,000$, and received about $\$ 24,000$. He claimed a loss of $\$ 26,000$, which was denied, partly because it was artificially inflated by a redemption price of $\$ 48$ per share for stock worth about $\$ 82$ per share. Another ground was that the distribution was not a true "liquidating distribution" because the corporation was not in the process of winding up. But the decision also suggests that the shareholder's loss was not yet determinable because, despite the surrender of shares, his control of the corporation and financial interest in its operations remained unchanged. On this theory, the basis of the surrendered shares should be added to the basis of the remaining shares and the distribution should be treated either as a dividend or as a partial return of capital. In Kelly v. Commissioner, 97 F.2d 915 (2d Cir. 1938), involving a pro rata retirement of stock, the court allowed the loss claimed by one of the shareholders, distinguishing Hellman v. Helvering, supra, as follows: "The basis of the court's decision was the fact that the taxpayer owned all the stock in the corporation and controlled its actions, and that the transaction in question was a bookkeeping manipulation to create a loss rather than a bona fide attempt to retire part of the outstanding stock." Kelly v. Commissioner, supra at 917. See also Malone v. Commissioner, 128 F.2d 967 (5th Cir. 1942), following the Kelly case and taking the surprising position that the loss is allowable even if the corporation pays less than the value of the stock, which would allow shareholders to create artificial losses by manipulating the price. In the Kelly and Malone cases the Tax Court had disallowed the claimed losses, relying on Hellman v. Helvering. In doing so, the Tax Court had expressly stated that the distributions giving rise to the claimed losses were not distributions in partial liquidation, though it is not clear why they were not nor why that should be relevant. Lida E. Malone, 45 B.T.A. 305, 310 (1941); Orie R. Kelly, 36 B.T.A. 507, 516 (1937). The Tax Court has disallowed a claimed loss on the surrender of stock for the purpose of improving the corporation's capital structure (e.g., to remove a deficit) on the ground that the transaction was a contribution to capital. Bed Rock Petroleum Co., 29 B.T.A. 118 (1933) (surrender for nominal consideration). But see Estate of William H. Foster, 9 T.C. 930 (1947) (non-pro rata surrenders); Julius C. Miller, 45 B.T.A. 292 (1941). 
but the statutory foundation for such adjustments was flimsy. ${ }^{157}$ The I954 Code is no better, but the Treasury for the first time has stated in the Regulations that in such cases "proper adjustment of the basis of the remaining stock will be made with respect to the stock redeemed."15s Where the corporation has several shareholders and all the stock of one shareholder is redeemed in a transaction that is taxed as a dividend (e.g., because he constructively owns the remaining shares), the "proper adjustment" may be to transfer the basis of the redeemed shares to the shares owned by the related shareholders, as the Regulations acknowledge. ${ }^{159}$

\section{The Basis of Distributed Property}

If the shareholder receives property, rather than money, on the redemption of his stock, he must assign a basis to it for computing depreciation, gain or loss on a sale, etc. If the property is received in a distribution in partial liquidation and if gain or loss is recognized on its receipt, section 334 provides expressly that its basis shall be its fair market value at the time of distribution. ${ }^{160}$ If the value of the distributed property happens to be exactly equal to the adjusted basis of the redeemed shares, so that gain or loss is not recognized on the exchange, section 334 (a) does not explicitly prescribe the basis of the property, but presumably here too fair market value is to be used. ${ }^{101}$ If the property is distributed in a non-

157. Katcher, The Case of the Forgotten Basis: An Admonition to Victims of Internal Revenue Code Section 115 (g), 48 Mrch. L. Rev. 465, 468-69, 470-71 (1950). On several occasions, courts have held that a redemption constituted a sale of the stock rather than a taxable dividend under $\$ 115(\mathrm{~g})$ of the 1939 Code, partly because they thought that otherwise the shareholder's basis would be forfeited. Commissioner v. Snite, 177 F.2d 819, 823 (7th Cir. 1949); Penfield v. Davis, 105 F. Supp. 292, 307-8 (N.D. Ala. 1952), aff'd, 205 F.2d 798 (5th Cir. 1953).

158. T.D. 6152, 26 C.F.R. $\$ 1.302-2$ (c) (1955). On the facts set out in the text, $A$ would hold the remaining stocls of Corporation $X$ at a basis of $\$ 100,000$. Id. at example 1 .

159. Id. at example 2 .

160. Section 334(a) provides that the basis of the distributed property is its fair market value at the time of the distribution if gain or loss is "recognized" on its receipt. The term "recognized" probably means "recognizable." See Corpus Christi Terminal Co., 38 B.T.A. 944, 947 (1938). See also Gloyd v. Commissioner, 63 F.2d 649 (8th Cir.), cert. denied, 290 U.S. 633 (1933) (no suggestion of estoppel). A taxpayer who was required, but failed, to report gain on the partial liquidation is probably not estopped to claim a stepped-up basis for the property received, since the government is apparently protected by $\$ 1312(6)$. The partial liquidation seems to be a "transaction on which . . . basis depends" within the meaning of $\$ 1312(6)$, even though $\$ 334(a)$ does not tie the basis to the gain that should have been recognized quite as clearly as, for example, $\S 358(\mathrm{a})$. See Mintz \& Plumb, Taxing Income in Years Not Realized Under Doctrine of Equitable Estoppel, 1954 So. Calif. TAx INst. 481, 542-47.

161. In the absence of some other statutory provision prescribing the property's basis, its basis is "cost." INT. REv. CODE of 1954, \$1012. Ordinarily there would be no difference between the fair market value of the property received and the fair market value of the stock redeemed. See pp. 51-52 supra. As to which is controlling if there is a 
dividend redemption under sections $302(\mathrm{~b})$ or 303 , the Code does not state explicitly how its basis to the shareholder is to be determined. ${ }^{162}$

If the property is distributed in a redemption that is, by virtue of section 302(d), treated as a section 301 distribution, its basis to the shareholder is determined under section $30 x$ (d). If the recipient is not a corporation, the basis of the property is its fair market value. If the recipient is a corporation, the basis is the property's fair market value or its adjusted basis in the hands of the distributing corporation, adjusted for gain recognized under sections $3 \mathrm{II}(\mathrm{b})$ or $3 \operatorname{II}(c)$, if any, whichever is less.

\section{Recognition of Corporate Income}

Section 336 provides, as did the Regulations under the $x 939$ Code, ${ }^{163}$ that no gain or loss shall be recognized by a corporation upon the distribution of appreciated or depreciated property in partial or complete liquidation. By virtue of section 453 (d), the distribution of installment obligations is an exception to this general rule-the corporation recognizes gain or loss to the extent of the difference between the fair market value of an installment obligation and its basis.

If a corporation distributes property in a redemption that is treated as an ordinary distribution under section 3or, its recognition of gain or loss is governed by section.3Ir. Gain or loss is not recognized unless the corporation distributes installment obligations, certain LIFO inventory or property subject to, or in connection with which the shareholder assumes, a liability in excess of the property's basis. The rules of section 3II are probably equally applicable to a redemption that qualifies for capital gain or loss treatment under section 302(b). If so, the recognition of gain on the distribution of certain types of property (i.e., certain LIFO inventory and property with liability in excess of basis) in redemp-

disparity between them, see Philadelphia Park Amusement Co. v. United States, $130 \mathrm{Ct}$. Cl. 166, 126 F. Supp. 184 (1954); Greenbaum, The Basis of Property Shall Be the Cost of Such Property: How Is Cost Defined?, 3 TAx L. Rev. 351 (1948). Note that if the basis of the distributed property were not its fair market value, but the fair market value of the stock redeemed (assuming a discrepancy), an unwarranted distinction would be created between property received in a partial liquidation producing a trivial amount of gain or loss and that producing neither gain nor loss.

162. See note 160 supra. See also Gloyd v. Commissioner, 63 F.2d 649 (8th Cir.), cert. denied, 290 U.S. 633 (1933); Marcus Schlitt, 7 CCH Tax Ct. Mem. 354 (1948) (complete liquidation).

163. U.S. Treas. Reg. 118, 39.22 (a)-20 (1953). 
tion of stock would depend for no apparent reason of policy upon whether the redemption was a partial liquidation or a section 302(a) redemption, even though both are treated by the shareholder as sales of the stock. On the other hand, if section 3II is not applicable to the nondividend redemption ${ }^{164}$ the effect on the corporation of redeeming its stock under section 302 (a) with appreciated or depreciated property would be governed by pre-I954 case law, under which no gain or loss would be recognized. ${ }^{165}$ This, in turn, would put redemptions of this type on a plane of equality with redemptions in partial liquidation of the corporation. ${ }^{286}$

Even though the distribution of appreciated property does not itself ordinarily produce taxable income to the corporation, income realized in form by the shareholders following the distribution may be imputed to the corporation in accordance with the Court Holding Co. case. ${ }^{187}$ and similar doctrines, e.g., in the case of a prearranged sale of property by the shareholders after a corporate sale was called off. ${ }^{168}$ These principles apply to a distribution of property in redemption of stock, whether the redemption constitutes a dividend under section 302 (d), a sale of stock under section 302(a) or a partial liquidation under sections $33 \mathrm{r}(\mathrm{a})(2)$ and $346 .^{169}$ The

164. It is arguable that $\S 311(\mathrm{a})$, which by its terms is concerned with distributions by a corporation "with respect to its stock," does not apply to $\$ 302$ (a) redemptions, because they are to be treated as distributions "in part or full payment in exchange for the stock." For another example of this problem of construction, see note 173 infra.

In at least one situation, $\$ 311$ is clearly not applicable to a redemption of stock. If a shareholder purchases property from the corporation and pays for it with stock, the transaction is not a "distribution, with respect to its stock" within the meaning of $\$ 311$. Senate Report 247; T.D. 6152 , 26 C.F.R. $\$ 1.311-1$ (e)(1), (2) (1955). But this exclusion is concerned with transactions "between a corporation and a shareholder in his capacity as debtor, creditor, employee, or vendee, where the fact that such debtor, creditor, employee, or vendee is a shareholder is incidental to the transaction." Ibid. The purpose of the exclusion is not to relieve the corporation from recognizing income under $\$ 311(\mathrm{~b})$ and $\$ 311(\mathrm{c})$, but rather to deny the use of $\S 311$ (a) to eliminate income on a sale where the corporation happens to be paid in its own stock. The exclusion is not in itself broad enough to make $\$ 311$ inapplicable to all $\$ 302$ (a) redemptions, but, on the other hand, it should not lead to the negative inference that all other transactions by which the corporation exchanges property for its own stock are subject to $\$ 311$ (b) and (c).

165. General Util. \& Operating Co. v. Helvering, 296 U.S. 200 (1935).

166. On a distribution of installment obligations in a $\$ 302(a)$ redemption, income would be recognized by virtue of $\$ 453(\mathrm{~d})$, just as in the case of a distribution of such obligations in partial liquidation.

167. Commissioner v. Court Holding Co., 324 U.S. 331 (1945).

168. Ibid. See also United States v. Cumberland Pub. Serv. Co., 338 U.S. 451 (1950); T.D. 6152, 26 C.F.R. $\$ 1.346-3$ (1955); Bittker, Stock Dividends, Distributions in Kind, Redemptions, and Liquidations Under the 1954 Code, 1955 So. Calif. TAX INST. 349, 360-64; Mintz \& Plumb, Dividends in Kind-The Thunderbolts and the New Look, 10 TAX L. REv. 41, 45-50 (1954).

169. Section 337, providing that the corporation shall not recognize gain or loss on certain sales of property within the 12-month period following the adoption of a plan of complete liquidation, has no application to property distributed in redemptions that are not complete liquidations. 
courts may be more ready, however, to impute income to the corporation upon the sale of property, especially inventory, if it was distributed in a section 302 (d) or section 302 (a) transaction rather than in partial liquidation of the corporation. ${ }^{170}$

\section{Effect on Earnings and Profits}

The effect of a redemption of stock on the corporation's earnings and profits depends upon whether the redemption is treated as a distribution under section 301 or as an exchange of the stock under section $302(a)$ or sections $33 \mathrm{I}(\mathrm{a})(2)$ and $346^{171}$ If the redemption is treated as a distribution of property under section 30I, the corporation's earnings and profits are to be adjusted under section $3 \mathrm{I} 2$ in the same way as upon any other dividend, i.e., earnings and profits are reduced by the amount of money, the principal amount of any obligations, and the adjusted basis of any other property distributed, with special adjustments in the case of a distribution of appreciated inventory assets, LIFO inventory, or property subject to liabilities. If the redemption is a partial liquidation or is treated as a sale of the redeemed stock under sections $302(\mathrm{a})$ or 303, however, section 3I2(e) provides that the portion of the distribution which is "properly chargeable to the capital account" shall not be treated as a distribution of earnings and profits. Neither the Senate Report nor the Regulations explained how the amount "properly chargeable to capital account" is to be computed, even though pre-r954 law was in a state of confusion. ${ }^{172}$ After the proper amount has been ascertained and deducted, the balance of the distribution presumably reduces earnings and profits in accordance with the rule of section 3I2(a), as modified by sections $3 \mathrm{I2}(\mathrm{b})$ and $3^{\mathrm{T} 2}$ (c). ${ }^{173}$ If the partial liquidation or redemption under sections

170. See United States v. Lynch, 192 F.2d 718 (9th Cir. 1951), cert. denied, 343 U.S. 934 (1952).

171. The corporation may not know whether a redemption constituted a dividend or a sale, either because the issue is in litigation or because the corporation cannot ascertain such critical facts as whether a shareholder was, at the time of the redemption, the constructive owner of shares registered in another's name. For a recent instance of a corporation that did not know, and could not find out, whether it was a personal holding company, see Coshocton Securities Co., 26 T.C. No. 117 (Aug. 14, 1956).

Note also that if the shareholder has relied upon $\$ 302(\mathrm{c})(2)$ for relief from the constructive ownership rules, a distribution that appears to come under $\$ 302$ (a) may turn out to be a $\$ 301$ distribution if the distributee acquires a disqualifying interest in the corporation within the following ten years.

172. St. Louis Co. v. United States, 237 F.2d 151 (3d Cir. 1956); Albrecht, "Dividends" and "Earnings or Profits", 7 TAx L. Rev. 157, 200-207 (1952).

173. Section 312 (a) refers to "the distribution of property by a corporation with respect to its stock," while a redemption that meets the standards of $\$ 302(\mathrm{~b})$ is to be treated, according to $\$ 302(a)$, "as a distribution in part or full payment in exchange for the 
302 (a) or 303 is not pro rata, the remaining shareholders would suffer unless an appropriate portion of the liquidating distribution is charged to earnings and profits. But where all shareholders participate equally in the liquidating distribution, it is not easy to defend a reduction in earnings and profits on the occasion of a distribution that is not taxed as a dividend. ${ }^{174}$

stock." It might be argued that a distribution in exchange for stock is not a distribution with respect to the stock (see note 164 supra), but the fact that $\S 312$ (e) states a "special rule" following the "general rule" of $\$ 312(a)$ suggests that after the proper charge to capital account has been made, the reduction in earnings and profits is governed by $\S 312$ (a). If so, new complications in applying $\$ 312$ (e) are introduced by $\$ 312(\mathrm{a})(3)$. If a distribution of $\$ 50,000$ in cash would be charged $\$ 40,000$ to capital and $\$ 10,000$ to earnings and profits, what is the charge upon a distribution of property worth $\$ 50,000$ but having an adjusted basis of $\$ 45,000$ ? Of $\$ 75,000$ ?

174. A reduction in earnings and profits where no dividend tax has been paid by the shareholders is not made less anomalous by the fact that there are other instances, such as the distribution of depreciated property under $\$ 312(a)(3)$, of the same phenomenon. 